\title{
Reşit Saffet Atabinen (1884-1965) ve Türk Turizmine Katkıları

\author{
Reșit Saffet Atabinen (1884-1965) and his Contributions to \\ Turkish Tourism
}

\author{
Ahmet ALTINTAŞ* \\ Feyza KURNAZ ŞAHIN**
}

$\ddot{O} z$

Reşit Saffet Atabinen, Osmanlı Devleti'nin son dönemlerinde doğmuş, ülkenin içinde bulunduğu birçok sorunu yaşamış, Milli Mücadele ve daha sonraki dönemlerde Mustafa Kemal Atatürk'ün yantnda yer almış çok yönlï, gerçek bir Türk aydınıdır. $O$, battyı çok iyi tanıyan bir diplomat, döneminin önemli tarihçilerinden birisi, Atatürk'e çok yakın bir milletvekili ve gerçek bir Türkiye sevdalısıdtr.

Bu çalş̧mada Reşit Saffet Atabinen' in farklt yönlerine değinmekle birlikte esas olarak turizmci yönü ortaya konulmaya çalışlacaktur. Onun tek amact Türklerin ve Türkiye'nin dünyada hak ettiği biçimde ve doğru bir şekilde tanitılması olmuştur. Bunun için Atatürk'ün isteği ile 1923 ytlından itibaren turizmle ilgili fikirlerini uygulamaya başlamış ve bu tarihten sonra gerek batıda gerekse doğuda Türk turizminin doğru bir șekilde tanttılması konusunda elinden geleni yapmıștır. Onun turizm alanındaki fikir ve çalışmalart bugünkü çaltşmalara tşık tutmuş çok modern bir turizm bakışıder.

Anahtar kelimeler: Reșit Saffet Atabinen, Turizm, Turing

Abstract

Reşit Saffet Atabinen is a qualified and a real Turkish intellectual who was born in the last years of Ottoman Empire, who experienced a lots of problems of the

* Yrd. Dof. Dr., Afyonkarahisar Kocatepe Üniversitesi, Fen-Edebiyat Fakültesi, Tarih Bölïmü Ögretim Üyesi, (el-mek: aaltintas@aku.edu.tr).

"* Afyonkarahisar Kocatepe Üniversitesi, Sosyal Bilimler Enstitüsü, Cumhuriyet Tarihi AnabilimDalı Doktora Ögrencisi, (el-mek: kurnazfeyza58@mynet.com) 
country and who was near Mustafa Kemal Atatürk during and after the National Struggle period. He was a diplomat who knew the West very well, he was one of the important historians of his period and he was a deputy who was very close to Atatürk and a real lover of Turkey.

In this study, besides mentioning about different aspects of Reşit Saffet Atabinen, we especially try to show his characteristics in tourism field. His only purpose was Turkish people's and Turkey's being introduced as they deserved and correctly in the world. For this reason, with the desire of Mustafa Kemal Atatür, he started to apply his ideas about tourism in 1923 and after this date, he did his best for the sake of Turkish tourism's being introduced correctly both in West and East. His ideas and studies in tourism field are very modern tourism views which enlighten today's studies.

Key Words: Reşit Saffet Atabinen, Tourism, Turing

\section{GİRIŞ}

Diplomat, siyaset adamı ve entelektüel bir kişi olan Reşit Saffet Atabinen, döneminin çok yönlü bir aydınıdır. O, 1927 ve 1931 yıllarında III. ve IV. dönem Kocaeli milletvekilliği yapmış ${ }^{1}$, Türk Tarih Cemiyeti'nin kurucu üyeliği ${ }^{2}$ ve Academie des Sciences Morales et Politiques'in ilk Türk muhabir üyeliği gibi pek çok görevi üstlenmiştir ${ }^{3}$. Onun hayatı hakkında bilinenler, faaliyetleri, kendisinin nedenli önemli işler yaptığını anlamaya yeterlidir. Fakat biz Reşit Saffet Atabinen'in devlet adamlı̆̆ı veya siyasetçiliği dışında turizmci yönü üzerinde durup bu yönünü ortaya koymaya çalışacağız. Onun turizmle ilgili yaptıklarına bakınca Türk turizminin öncüsü, yaşatıcısı ve esaslı şekilde geliştiricisi olduğunu

\footnotetext{
${ }^{1}$ III. dönem milletvekilliği için bkz. Kazım ÖZTÜRK, Türk Parlamento Tarihi, TBMM III. Dönem 1927-1931, III. Cilt, TBMM Vakfi yay. No. 10, Ankara 1993, s. 400-401; IV. dönem milletvekilliği için bkz. Fahri ÇOKER, Türk Parlamento Tarihi, TBMM IV. Dönem 1931-1934. II. Cilt, TBMM Vakfi yay. No. 12, Ankara 1993, s. 372; TBMM III. Dönem seçimlerine katıldı. Ticaret ve Maliye Komisyonlarında çalıștı. Paris'te toplanan Uluslararası Parlamentolar Ticaret Konferansına, Yüce Meclis adına katılması 7 Nisan 1928'de kabul edildi. Gümrük Tarifeleri Kanununun değiștirilmesine dair kanun teklifi vermiștir. Yine o, 20 Mayıs 1928 tarihine Erzincan mebusu Saffet, Corum mebusu Mustafa ve Balıkesir mebusu Sadık Bey'ler ile ortaklaşa Uluslararası Rakamların Kabulü ve Kullanılmasına dair ortaklaşa bir teklif vermisler, neticede 24 Mayıs 1928 tarih ve 1288 sayılı kanun ile Uluslararası Rakamların Kabulü ve Kullanılması kabul edilmiştir. 1 Haziran 1928'de de yürürlüğe girmiştir. Bkz. TBMM Zabıt Ceridesi, (3 Mayıs 1928-24 Mayıs 1928), Devre III, C. IV, Ictima senesi I, 202-209, 221-222.

$2^{2}$ Atatürk Günlüğü, 1930, (Der. Orhan Topçuoğlu) 2. baskı, Demircioğlu Matbaacılık, Ankara 1989, 34-35; Abdülhak Şinasi HISAR, "Reşit Saffet Atabinen ve Tarihimize Dair Eseleri", Türk Yurdu, (Ekim 1955), S. 249, s. 278.

${ }^{3}$ Mahmut ŞAKİROGLU, Reşit Saffet Atabinen Bibliyografyast, Türkiye Turing ve Otomobil Kurumu yay., İstanbul 1985, s. 6; "Reșid Saffet ATABINEN", Türk Kültürü, S. 29, Y1l III, (Mart 1965), s. 52-53; Celik GÜLERSOY, "Ölümünün 29. Yılında Reşid Safvet Atabinen", Tarih ve Toplum, (Şubat 1994), C. 22, S. 122, s. 68.
} 
söylemek sanırız abartılı olmayacaktır ${ }^{4}$. Ancak Reşit Saffet Atabinen'in ilk olarak hayatı hakkında bilinenlere kısaca bir göz atmak yerinde olacaktır.

\section{Raşit Saffet Atabinen'in Hayatı}

Reşit Saffet, 4 Eylül 1884'de İstanbul'da Sarıer'de annesinin babası Bedestânî Mustafa Efendi'nin yalısında doğmuştur ${ }^{5}$. Babası Mızıka-i Hümayun eski Miralayı Saffet Bey, annesi Fatma Saliha Hanım'dır. Annesi Şemseddin-i Sivasi torunlarından Haşim Efendiye dayanırken babasının soyca Danişmetlerin Tosya kolundan olduğu anlaşılmaktadır. Reșit Saffet Bey, II. Abdülhamid'in Seraskeri Rıza Paşa'nın ikinci oğlu Şükrü Paşa'nın damadıdır. Reşit Saffet Bey, Şükrü Bey ile Kevser Hanımın kızı olan Nurhayat Hanımla evlenmiş, Fatma Nükhet, Mustafa Gümüştekin ve Hatice Gültekin isimlerinde üç çocuğu olmuştur ${ }^{6}$.

Küçük yaştan başlayarak mürebbiye ve özel öğretmenlerden ders alan Reșit Saffet, Kadıköy Frerler Kolejine girerek buradan 1900'de mezun olmuştur. 1904'de Paris'te "Ecole Libre de Science Politiques"den diploma almış, Fransızcayı da ana dili gibi kullanabilmeyi öğrenmiştir. 1904'de Tütün Rejisi Komiserlik Kalemi Mütercimliği'ne atanmış, aynı zamanda İngilizce ve Fransızca olarak çıkan Levant Herald ${ }^{7}$ gazetesi başyazarlığı, Sadrazam Avlonyalı Ferit Paşa'nın Özel Kalem Müdürlüğü'nü yapmıștır' Daha sonra Bâb-1 Âli Yazı İşleri Hariciye kalemine alınmıştır. 1907'de Türkiye-Romanya Karma Komisyonu Başkâtibi, 1908'de Bükreş Sefareti Başkâtip Vekili, sonra sırasıyla Washington, Madrid ve Tahran Sefaretleri Başkâtibi olarak çalıșmıș, 1912'de Büyükelçilik Müsteșarı unvanı ile Maliye Özel Kalemi Müdürlüğüne atanmıştır. 1913'te İçişleri Bakanı Talat Bey tarafından Edirne Kurtuluş Heyeti Reisi olarak Londra ve Romanya'ya gönderilmiş ${ }^{9}, 1914-1918$ yıllarında Maliye Bakanı Cavit Bey'in yanında Viyana ve Berlin'deki mali görüşmelere katılmıştır. 1918-1920 yıllarında

\footnotetext{
${ }^{4}$ Selâhattin ÇORUH, "R. Saffet Atabinen", Türkiye Turing ve Otomobil Kurumu Belleteni, 276-279, (Ocak-Nisan 1965), s. 9; Hayat Tarih Mecmuast, 1965/4, (Mart 1965)'dan naklen "Ölümü Dolayısıyla: Reşid Saffet Atabinen", Türkiye Turing ve Otomobil Kurumu Belleteni, 276-279, (Ocak-Nisan 1965), s. 12.

s"Reşid Saffet ATABINEN", Türk Külttürü, S. 29, Y1l III, (Mart 1965), s. 52-53.

${ }^{6}$ ÖZTÜRK, a.g.e., s. 400; Hayat Tarih Mecmuast, 1965/4, (Mart 1965)'dan naklen "Ölümü Dolayısıyla: Reşid Saffet Atabinen", Türkiye Turing ve Otomobil Kurumu Belleteni, 276-279, (Ocak-Nisan 1965), s. 12.

Kazım Öztürk, Türk Parlamento Tarihi adlı eserinde R. Saffet'in başyazarlık yaptığı gazetenin "Le Mond Herald" olduğunu ifade etmektedir. Bkz. ÖZTÜRK, a.g.e., s. 400.

"GÜLERSOY, "Reșid Safvet Atabinen", s. 68 vd; "Reșid Saffet ATABINEN", Türk Kültürü, S. 29, Y1l III, (Mart 1965), s. 52-53.

${ }^{9}$ R. Saffet Bey, 1912 yılında Roma'da iken Dışişleri Bakanı Kont Sforza tarafından Edirne'ye girilerek bir oldubitti ile bu şehrin geri alınmasını tavsiye eder. Reşit Saffet Bey de bu tavsiyeyi Enver Paşa'ya iletir ve Edirne geri alınır. 1930 yılında Kazım Dirik tarafından Reşit Saffet'e fahri hemsehrilik verilir. Bkz. GÜLERSOY, "Resid Safvet Atabinen", s. 69-70; keza bkz. Fethi ERDEN, "R. Saffet Atabinen", Türkiye Turing ve Otomobil Kurumu Belleteni, 276-279, (Ocak-Nisan 1965), s. 8.
} 
İsviçre'de ulusal bağımsızlığın tanıtımı için kitap ve makaleler yayımlamış ve konferanslar düzenlemiştir ${ }^{10}$.

Eylül 1921 yılında Şûrâ-yı Devlet (Danıştay) Tanzimat Dairesi üyeliğine getirilen Reșit Saffet Bey, 1922'de Lozan Sulh Konferansının ilk bölümünde Türk Murahhas heyetinin genel sekreterliğini yapmıştır ${ }^{\prime \prime}$. 1923-1927 yıllarında Memalik-i Şarkiye Fransız Bankası müşavirliğinde, Anadolu Bağdat Demiryolları Meclis başkan yardımcılığında ve değişik şrketlerin yönetim kurullarında görev yapmıș keza Hudut Sıhhiye Tasfiye Komisyonu üyeliğinde ve Cenevre Uluslararası İktisat Konferansı müşavirliğinde de bulunmuştur ${ }^{12}$. 1927-1931 ve 1931-1934 yıllarında III. ve IV. dönemlerde milletvekilliği yaptığı sırada Avrupa'nın değişik kentlerinde toplanan uluslararası bilimsel, ekonomik ve politik kongre ve konferanslara Türk delegesi olarak katılan Reșit Saffet, 4 kez başyazarlık üstlenmiș ve Türk Ocakları Hars Heyeti Genel Sekreterliği'nde bulunmuştur ${ }^{13}$. Türkiye Turing ve Otomobil Kurumu Kurucu başkanı olmuş ve Atatürk'ün jestiyle 1933 yılından 1955 yılına kadar Uluslararası Olimpiyat Komitesi Türkiye temsilciliği görevini yürütmüştür ${ }^{14}$.

Reşit Saffet Bey, M. Kemal Atatürk'le mütareke yıllarından ve Akaretlerdeki komşuluklarından tanışmaktadır ${ }^{15}$. Bu yakınlık 1920'lerde de devam etmektedir. Nitekim o, Roma'dan 27 Temmuz 1920 tarihinde Atatürk'e yazdığ mektupta “Muhterem Paşacı ğım, Ferit Paşanın ikinci bir tevkif teşebbüsü ile buraya geldim. Salih Paşa kabinesinin son günlerinde, Sadâret-i uzmânın emriyle vâkî olan teşebbüsatım malûmu âlileridir. Aynı esas üzere ve ayni program dahilinde çallşmak üzere bir ay sonra buradan hareketle Paris'e gitmek niyetindeyim... Cevabınıza intizâren a'zâmi muvaffakiyetler için te "minatı kalbiyemi tekrar ve en samimi hürmetlerimi tekid eylerim ferman" demektedir ${ }^{16}$. Ayrıca 1930-1938 yılları arasında Reşit Saffet Bey'le Atatürk'ün ilişkileri son derece iyidir. Atatürk, Büyük Nutkun Fransızca'ya çevrilmesini ona emanet etmiş ve o da 1927 yılında Dolmabahçe'de bu görevi yerine getirmiștir ${ }^{17}$. Keza o, Avrupa aydın ve

${ }^{10}$ ÖZTÜRK, a.g.e., s. 400-401; "Reșid Saffet ATABINEN", Türk Kültürü, S. 29, Yıl III, (Mart 1965), s. 52-53.

"Gazi Mustafa Kemal ATATÜRK, Nutuk-Söylev, 1919-1920, I. Cilt, 3. Baskı, TTK yayın, Ankara 1989, s. 332-333; GÜLERSOY, "Reşid Safvet Atabinen", s. 70.

${ }_{12}^{12}$ ÖZTÜRK, a.g.e., s. 401

${ }^{13}$ Abdülhak Şinasi HISAR, "Reşit Saffet Atabinen ve Tarihimize Dair Eseleri", Türk Yurdu, (Ekim 1955), S. 249, s. 278.

${ }^{14}$ GÜLERSOY, "Reşid Safvet Atabinen", s. 71

${ }^{15}$ Asım US, "Reşid Saffet Atabinen", Türkiye Turing ve Otomobil Kurumu Belleteni. 276-279, (Ocak-Nisan 1965), s. 7.

${ }^{16}$ Bilal ŞıMŞiR, Atatürk Ille Yazışmalar, 1920-1923, Kültür Bakanlığı yayınları, Ankara 1992, s. $9,75-76$

${ }^{17}$ US, a.g.m., s. 7; GÜLERSOY, "Reșid Safvet Atabinen", s. 70; Türkiye'ye Bir Işıktı Turing 1977-1993 (1-Doğum ve Emekleme), s. 9. 
siyasal çevrelerine Türklerin tarihi haklarını ve Türk kültürünün Dünya medeniyetine katkılarını ortaya koymak için pek çok çaba göstermiştir ${ }^{18}$.

Reşit Saffet Atabinen'in çok yönlü ve entelektüel bir kişi olduğu açıkça görülmektedir. Yukarıda saydığımız özellikleri dışında ek olarak 1913 yılında İstanbul'da Maliye Mektebi'nde ders verdiği ${ }^{19}, 1929$ Aralık ayında Mustafa Kemal Atatürk'ün himayesi altında kurulan "Milli Íktisat ve Tasarruf Cemiyeti"nin kurucuları arasında bulunduğu ${ }^{20}, 1931$ yılında Atatürk'ün direktifleri ile bütün memlekete örnek olacak ve Ankara'da kurulacak kooperatiflerin teşkilatlarının esaslarını ve nizamname müsveddelerini Ziraat Bankası Meclisi İdaresi azasından Cevdet Nusuhi Bey ile hazırladığ ${ }^{21}$, 1933-1952 yılları arasında Uluslararası Olimpiyat Komitesi'nde ülkemizi temsil ettiği bilinmektedir. Keza onun 1933-1936 yılları arasında Türkiye Milli Olimpiyat Komitesi başkanı olarak da görev yaptığı görülmektedir ${ }^{22}$. Reşit Saffet Bey'in milletvekilliği görevi sona erdikten sonra kurucusu olduğu Türkiye Turing ve Otomobil Kurumunun başkanlığında kaldığı, bu renkli ve yoğun görevlerini arttırarak sürdürdügü anlaşılmaktadır ${ }^{23}$.

Reșit Saffet Atabinen, 1.8.1930 tarihinden itibaren "Türkiye Turing Ve Otomobil Kurumu Belleteni" (Bulletin Officiel du Touring et Automobile Club de Turquie) isimli bir dergi çıkarmaya bașlamıștır ki bu dergi kesintisiz yayın hayatında kalması ile en eski dergilerden birisi olmuştur ${ }^{24}$. Atabinen'in derginin yazı işlerini fiilen idare ettiği görülmektedir ${ }^{25}$. İstanbul'un 500 'üncü fetih kutlamalarını, Avrupa ülkelerinde bilimsel düzeyde o yönlendirmiştir ${ }^{26}$. Hatta bu konudaki düşünce ve program on iki sene önceden hazırlanarak ilgili makamlara sunulmuştur ${ }^{27}$.

\footnotetext{
${ }^{18}$ M. ŞAKIROĞLU, age, s. 7-8; keza Türkiye'ye Bir Işıktı Turing 1977-1993 (1- Doğum ve Emekleme), s. 9.

${ }^{19}$ SAKIROĞLU, a.g.e., s. 11.

${ }^{20}$ Çelik GÜLERSOY, "Reşit Saffet Atabinen'i Anma Toplantımız", Türkiye Turing ve Otomobil Kurumu Belleteni, 79-358, (1990), s. 5

${ }^{21}$ Atatürk Günlü̆̆̈̈, 1931, (Der. Orhan Topçuoğlu) 2. baskı, Demircioğlu Matbaacılık, Ankara 1989, 15-16.

${ }^{22}$ Cüneyt E. KORYÜREK, Olimpiyadlar, 2003, s. 125

${ }^{23}$ ÖZTÜRK, a.g.e., s. 401-402.

${ }^{24}$ Türkiye Turing ve Otomobil Kurumu, 1923-1973, T.T. ve O. K.'nun 50. Ylll, Turing yayın, İstanbul 1973, s. 26.

${ }^{25}$ GÜLERSOY, "Reşit Saffet Atabinen'i Anma", s. 5; ayrıca bkz. Türkiye'ye Bir Ișılktı Turing 1977-1993 (1-Doğum ve Emekleme), Türkiye Turing ve Otomobil Kurumu Yayını, s. 8; US, a.g.m., s. 6; Reşat Ekrem KOÇU, Istanbul Ansiklopedisinde "Atabinen"'den naklen Türkiye Turing ve Otomobil Kurumu Belleteni, 276-279, (Ocak-Nisan 1965), s. 13-14.

${ }^{26}$ ÖZTÜRK, a.g.e., s. 401-402; GÜLERSOY, "Reșid Safvet Atabinen", s. 69.

${ }^{27}$ Türkiye Turing ve Otomobil Kurumu 30'uncu Yıl Dönümü, 5 Aralık 1923-1953, Çiturì Biraderler Basımevi, İstanbul [y-y]. s. 9.
} 
Reşit Saffet Atabinen'in 1940'lı yıllara kadar "Kara Şemsi” müstear adını kullandığı anlaşılmaktadı2 ${ }^{28}$. Bunun gerekçesini Çelik Gülersoy, Reşit Saffet Bey'in büyükbabası Dr. Ali Bey'in Şemseddin-i Sivasi soyundan Haşim Efendi'nin kızı Fatma Hanımla evli olmasına ve Kara Şemsi soyundan gelmesine bağlar ${ }^{29}$. Onun hayır işlerine de eğildiğini görmekteyiz. Reşit Saffet Bey, Tosya'da büyük bir mektep inşa ettirmiş, 22 Ekim 1949 tarihinde İstanbul'da Darüşşafaka müessesesine bir yüksek tahsil talebe yurdu yaptırarak vakfetmiştii ${ }^{30}$.

Yerli ve yabancı gazete ve dergilerde yazıları çıkmış, pek çok kitap yazmıștır. Keza Sabah Gazetesi'nde baș sayfada yazılar yazdığı anlaşılmaktadır ${ }^{31}$. 2 Şubat 1965 'te İstanbul'da prostat kanserinden ölmüştür. Mezarı 1950'lerde dönemin Cumhurbaşkanı Celal Bayar'ın aracılığıyla hayatta iken alınan Kocamustafapaşa'daki Sümbül Efendi Camii avlusundaki Haşim Efendi türbesine gömülmüştür ${ }^{32}$.

\section{II) Reșit Saffet Bey'in ve Türk Turizmine Bakıșı}

\section{a) Turizm Anlayışı}

Araştırmamızda esas olarak üzerinde duracağımız konu Reşit Saffet'in turizmci yönüdür. Reşit Saffet'e göre Turizm, Fransızca "tur" kelimesinden türemiştir ki devir, uzun boylu gezme ve gezinti demektir. Turizm, insanın araştırma ufkunu genişletmek, karşılaştırma kabiliyetini büyütmek, okuduğu veya okumadığı şeyleri bizzat görerek okumuş olmakla bilmekliğin farkına varmayı sağlamaktadır ${ }^{33}$.

Reșit Saffet Bey'e göre "az çok terbiye-i fikriyesi olmayan adam" turizm yapamaz. Turizm yapan gezdiği yerlerde ya tabiat güzelliklerinden lezzet alacak ya gezdiği yerlerin ahalisinin yaşayışını tetkik edebilecek ve abidelerin kıymetini anlayabilecek incelikte ve kudrette veya hiç olmazsa bunları merak edecek fikre sahip olmalıdır. Turizmin en büyük faydası insana farklı güzellikleri kıyaslamayı öğretmesidir. Reşit Saffet Bey’e göre

${ }^{28} \mathrm{M}$. ŞAKIROĞLU, age, s. 8.

${ }^{29}$ GÜLERSOY, "Resid Safvet Atabinen", s. 68, 73

${ }^{30}$ M. Mesud KOMAN, "Kaybettiğimiz İki Büyük Kıymet'e Ait Birkaç Satır", Türkiye Turing ve Otomobil Kurumu Belleteni, 276-279, (Ocak-Nisan 1965), s. 18.

${ }^{31}$ M. SAKİROĞLU, age, s. 11 .

${ }^{32}$ Ailesi Şemseddin-i Sivasi ile bağlantılı olduğundan Haşim Efendi ile bağlantısı oradan gelmekte idi. Geniş bilgi için bkz. Türkiye Turing ve Otomobil Kurumu, 1923-1973, s. 72: OZTÜRK, a.g.e., s. 402; KOMAN, a.g.m., s. 18; Reşit Saffet Bey'in ölümünden sonra varisleri eski eser olarak tescil edilmiş olan, Serasker Rıza Paşa'nın Konağı'nın mimari parçalarını, konağın eşyalarını, mermerleri sökülerek gizlice antikacılara haraç mezat satmıslardır. Bkz. GÜLERSOY, "Reșid Safvet Atabinen", s. 73; Türkiye'ye Bir Ișıktı Turing 1977-1993 (3- Gelișmeleri Seyreden Kurum), Türkiye Turing ve Otomobil Kurumu Yayını, s. 11 .

${ }_{33}$ Kara Şemsi Reşit Saffet [ATABINEN], Turizm'in Harsî, Siyasî ve İktisadî Faydaları, Türkiye Turing ve Otomobil Klöbü neşriyatından, No. 48, İstanbul [t-y], s. 3. 
medeniyet, milletlerin kimliğini kaybetmeksizin diğer milletlerle anlaşması, kaynaşma kabiliyetinin uyanması ve artmasıdır ${ }^{34}$.

Ona göre topluluklar arasındaki farklar ve milletlerin geçirdiği safhaları mümkün olduğu kadar yerinde görmek en faydalı öğrenme metodudur. Keza Türkiye'nin iki bin, üç bin yıllık tarihi yerlerini, eski eserlerini ve abidelerini tetkik etmek, Türk Milletine manevi kuvvet ve iftihar hissi veren en önemli şeydir ${ }^{35}$.

Reşit Saffet'in Avrupa, Rusya, İran ve Portekiz gibi dünyanın pek çok ülkesindeki gezilerinden edindiği kanaati şehirlerin ve ülkelerin kültür yerleşimlerinin, eski geleneksel özelliklerini, kişiliklerini korumaları gerektiğidir ${ }^{36}$. Ancak Cumhuriyetin ilk yıllarında gerek ekonomik sıkıntılar gerekse ülke nüfusunun değişmemesi sebebiyle Türkiye'nin turizmi ilgilendiren şekliyle kültürel özelliklerini koruma konusunda bir faaliyeti söz konusu olmamıștır.

Reşit Saffet Bey'in esas gayesi memlekete turist getirmeden önce, memleketi yabanc1 misafir kabul edecek hale getirmektir. Bu konuda o, "Ístanbul'un ortası ve büyük anıtlarl, bakımsızlıktan dökülür ve çökerken, yeşil sahalara milyonlar dökmenin ve resmi daire sarayları yapmanın, akıl ve mantıkla bağdaşır yanı yoktur" der. Yine Reşit Saffet Bey, memleketin her tarafında yapı zihniyetinden önce devamlı bakım zihniyetini yerleştirmekten yanaydı. Reşit Saffet, Türkiye'nin de doğru tedbirleri alması ile 8 milyonluk Katolik Avusturya gibi inançlarından ve kültüründen hiçbir taviz vermeden kendisinden çok fazla sayıda her milletten insana, kültür ve tabiat varlığını sunup bundan büyük gelirler elde edebileceğini ifade etmektedir ${ }^{37}$.

Bu konuda Fransa'nın su ve kaplıca şehri olan Vişi şehrini örnek veren Reşit Saffet Bey, asıl nüfusu 30.000'i geçmeyen bu șehre içme mevsiminde 120.000 turist geldiğini ve bu kişilerin hepsinin yaklaşık 20 gün kaldığını, hepsinin barınmasının, yemesinin, içmesinin temin edildiğini ifade etmektedir. Bu rakamlar haliyle turizmin fevkalade büyük ekonomik yönünü de göz önüne koymaktadır ${ }^{38}$.

Atabinen 1934'te Çifte Minarelerin, döner kümbetlerin, kervansarayların şerefini içinde duymak ve onları içselleştirerek, dünya turizmi içinde, insancıl amaçlarla kullanmak bilincini oluşturmaya çalışmışıı ı $^{39}$. Reşit Saffet Bey, turizm kavramını ve kelimesini Türkiye'ye ilk

${ }^{34}$ ATABINEN, Turizm' in Faydalarl, s. 3-4.

${ }^{35}$ ATABINEN, Turizm' in Faydalar, s. 5-6.

${ }^{36}$ GÜLERSOY, "Reşit Saffet Atabinen'i Anma", s. 4.

${ }^{37}$ GÜLERSOY, a.g.m., s. 7.

${ }^{38}$ ATABINEN, Turizm'in Faydalarl, s. 11

${ }^{39}$ GÜLERSOY, "Reşit Saffet Atabinen'i Anma", s. 6; keza Muhlis ETE, "Reşid Saffet 
kez ithal ettiği 1934 tarihli broşüründe turizmin kültürel siyasi ve iktisadi faydaları yanında çok genel ve çok temel iki kavramını getirmeye çalışmıştır. Bu kavram dış turizmden önce iç turizmdir. Bunda da deniz ve orman nimetlerinin yanında ülkenin kültürel varlığının, önce bilincine varmak, sonra benimsemek, sonra kullanmak ve onuruyla onurlanmaktır ${ }^{40}$.

Reşit Saffet Atabinen'in turizm alanındaki faaliyetleri son derece önemlidir. O, özelikle Anadolu'da Türklüğün "kâbeleri, milli ziyaretgâhları" bulunduğunu bildirdikten sonra buraları gezmemenin Türkler için garip karşılanacak bir durum olduğunu ifade eder. $\mathrm{O}$, Türk insanına Türkiye'yi sevdirmek ve gönülden bağlamak için ülkenin en güzel yerlerini tanıtmanın son derece önemli olduğunu ifade etmektedir. Böylece millet memleketine daha fazla bağlanacak ve bunları tanitmakla kendini mükellef hissedecektir. $\mathrm{O}$, Türklerin siyasi ve sosyal tarihini öğrenmek için öncelikle Türkiye'nin komşusu olan Bulgaristan, Yunanistan, Suriye, Kafkasya vs. bölgeleri gezmelerini tavsiye etmektedir ${ }^{41}$.

Atabinen'in önem verdiği konulardan birisi de yabancıların Türkiye'ye gelmesidir. Bu seyahatlerin hem iktisadi hem de siyasi faydaları bulunmaktadır. Uzun süreden beri devam eden ilişkilere rağmen Avrupa ve Amerika, Türkleri halen ya tanımaz ya da kötü tanır. Türkler ise Avrupalıları, Avrupa'da yazılmış kitaplardan veya tercümelerinden tanıdıklarından dolayı lehlerine tanırlar.

Avrupalılar ise Türkler hakkındaki fikirlerini Türkçe eserlerden veya Türklerin ağzından değil çoğunlukla Türkleri sevmeyen düşmanların, rakiplerin rivayetlerinden tanıdıkları için Türk Milletinin kabiliyetlerini, medeniyetini, ilerlemesini inkâr ederler. Reşit Saffet Bey'e göre, Türkiye'nin lehine, para vererek ismi cismi bilinmeyen kişilere yazdırılmış eserlerin hiç kıymeti ve tesiri bulunmamaktadır. Bu tür propagandaya para harcamak yerine; yabancı ülkelerin önde gelen insanların Türkiye'de misafir ederek gerçek Türkleri ve Türkiye'yi tanımasının önünü açmak daha faydalıdır ${ }^{42}$.

\section{b) Türkiye'nin Turizm Politikasının Belirlenmesi}

Atabinen'e göre Türklerin elinde dünyanın en zengin turizm sermayesi ve malzemesi vardır. Hem tabiat güzellikleri hem de geçmiş devirlere ait abidelerden turizm adına yeterince istifade etmemek büyük eksikliktir. Doğu'yu Batı için cazip kılan unsur zaten bu özellikleri ve keşfedilmemişliğidir. Bunun sonucu olarak Doğu seyahatlerinde İstanbul en çok görülmek istenen şehirlerin başında gelmektedir. İstanbul, Bursa ve Konya gibi şehirleri iyi şartlar altında görüp de Türklük lehine fikrini

Atabinen", Türkiye Turing ve Otomobil Kurumu Belleteni, 276-279, (Ocak-Nisan 1965), s. 7

4) GÜLERSOY, "Reşit Saffet Atabinen'i Anma", s. 6.

${ }^{41}$ ATABINEN, Turizm' in Faydalarl, s. 6-7.

${ }^{42}$ ATABINEN, a.g.e., s. 8-9. 
değiştirmeyen yabancı düşünülemez. Özellikle Atatürk'ün memlekette vücuda getirdiği yenilikleri kendi gözüyle görmek bir yabancı üzerinde daha derin tesir bırakabilmektedir. Reșit Saffet'e göre turizm; gayet kuvvetli, nazik, tesirli bir millî propaganda aletidir. Yalnız bir milleti tanımaya değil milletleri birbirine ısındırmaya da katkı sağlamaktadır ${ }^{43}$. Bu düșünceleri taşıyan Reşit Saffet, Türkiye'de ciddi anlamda turizm çalışmalarını başlatmıştır. Şüphesiz turizm konusunda bu derece entelektüel bir bakış açısına sahip olan bir aydının turizmle ilgili çalışmalarda bulunması Türkiye için önemli bir kazanım olmuştur.

O dönemlerde Türkiye'ye gelen turistlerin idari yönden belli başlı haklı şikâyetleri, Ekonomi Bakanlığına bildirilmiş, bunun üzerine bu meselelerin halli için Bakanlıklar arası bir turizm komisyonu kurularak konu üzerinde ciddi bir surette araştırmalara başlanmıştır. Böylece önce İktisat, Ticaret, Dâhiliye ve daha sonra da Başbakanlığa bağlı bir Basın-Yayın ve Turizm Umum Müdürlüğü, iller ve belediyeler nezdinde de müdürlük ve bürolar açılmıştır ${ }^{44}$. Türkiye'de turizm bakımından yapılacak yenilikleri ve düzenlemeleri gösteren bir turizm programı da cemiyet tarafından hazırlanarak Ekonomi Bakanlığına sunulmuştur ${ }^{45}$. Şöyle ki;

Bu programda son derece gerçekçi öneriler ve projeler bulunmaktadır.

- Turizm siyasetini bir program altında takip ve tatbik etmek, parti ve devlet teşkilatında bu meseleye gereken önemi vermek,

- Türkiye Turing ve Otomobil Kulübü'nün Başbakanlığa bağlanması ve bu şekilde faaliyet göstermesi,

- Devletin ilim, iktisat ve taşıma kurumlarının turizm ile alâkalarının tespiti, resmileştirilmesi ve maddi yardım temini,

- Film yapmak, konferanslar vermek, müzelerde incelemelerde bulunmak, öğrencilere memleketi tanıtmak,

- Turizmle ilgili müzeler, plajlar, içme, kaplıca, lokanta, tercüman vs.nin azami ölçüde ve tek elden düzenli çalışması,

- Devlet demiryollarının biletlerini satmak için bir resmi seyahat acentesi açılması ve kazancın propagandaya harcanması

- Yolların yapılması, tamir ve bakımı ve uluslararası işaretlerin yollara konulması,

\footnotetext{
${ }^{43}$ ATABINEN, a.g.e., s. 9-.

${ }^{44}$ Türkiye Turing ve Otomobil Kurumu 30'uncu Yll Dönümü, s. 4.

${ }^{45}$ Türkiye Turing Klöbü Ne Yaptı, (1925-1935), Türkiye Turing Kulübü yayını No. 72. İstanbul [1936?], s. 17-18.
} 
-Ulaşım ve diğer tedbirlerin uluslararası usullere uygun gerçekleştirilmesi,

-Bazı liman, fener vb. vergilerin turizmin gelişmesine tahsisi,

-Tren ve vapur seferlerinin düzenlenmesi,

-Ziyaret edilen bölgelerdeki otellerin temizliği, fiyatı vs.nin belediyelerce kontrolü,

- Tercüman, rehber ve şoför gibi yabancılarla ilk temasta bulunanların belirli bir seviyeye çıkarılması,

-Giriş çıkışlardaki pasaport işlemlerinin azâmî derecede kolaylaştırılması, tespiti,

- Kayıkçıların ve hamalların intizam altına alınması ve ücretlerinin

-Gümrük muamelelerinin kolaylaştırılması,

- Turizm bölgelerinde belediyelerin kontrolleri altında milli eğlence haftaları tertibi,

-İstanbul'da memleketin güzelliklerini ve Türk sanayi eserleri örneklerinin sergilendiği sergilerin açılması,

-Aynı sergilerin küçük ölçekte büyük istasyon ve limanlarda bulundurulmasi,

- Halka, turistlerin aldatılmamasının önemini anlatmak için basın yayın organlarının gayret göstermesi,

-Türkiye'yi manen ve maddeten sevdirici ve güzellikleri tanıtıcı eserlerin yayınlanmasının ve tercümesinin teşviki,

- Şehir ve köylerin medeni bir görünüme kavuşabilmeleri için ülke içinde geniş çaplı propaganda yapılması ${ }^{46}$.

Bu şekilde özetlenebilecek olan Reşit Saffet Atabinen'in turizm anlayışı dönemine göre çok ileri seviyededir. Bu dönemlerde devletin Türkiye'ye gelen turistlerle ilgili bir düzenlemesi ve planlaması bulunmadığı göz önüne alınacak olunursa bu çalışmaların dikkate değer olduğu görülebilir ${ }^{47}$. Reşit Saffet Bey, bu türden görüşlerini uygulama sahasına koyabilmek için M. Kemal Atatürk'ün de direktifleri ile 1923 yılında "Türk Seyyâhîn Cemiyeti"ni kuracaktır. Bu cemiyet 1926 y1lında "Türkiye Turing Klubü",

${ }^{46}$ ATABINEN, Turizm' in Faydalarl, s. 13-16.

${ }^{47}$ Türkiye Turing Klöbü Ne Yapth, (1925-1935), s. 5. 
1930 yılından itibaren ise "Türkiye Turing ve Otomobil Kurumu" adlarını alacaktır $^{48}$

\section{III) Reșit Saffet Bey'in Türk Turizmine Katkulart}

\section{a) Türkiye Turing ve Otomobil Kurumu}

Reşit Saffet Bey'in turizm ve Türkiye'ye daha çok turist gelmesine dönük en önemli faaliyetlerinden birisi yukarıda kısaca bahsettiğimiz üzere Türkiye'nin tanıtımında son derece büyük rol oynayacak olan Türk Seyyahin Cemiyetini, M. Kemal Atatürk'ün de direktifleri ile 29 Eylül 1923 tarihinde eski Kudüs Mutasarrıfı Cevdet Bey (Özoğul), Meclis-i Kebir Maarif azasından Mehmed Ziya Bey gibi bir grup aydın ile birlikte merkezi İstanbul'da olmak üzere kuracak ve ilk başkanı olacaktır ${ }^{49}$. Kurum ilk önce "Türk Seyyahin Cemiyeti", 1926 yılında "Türkiye Turing Klubü", 1930 yılından itibaren ise "Türkiye Turing ve Otomobil Kurumu" adlarını alacaktı $^{50}$. Bu kurucuların dişında kurumun önde gelen isimleri arasında Emekli Kurmay Albay Şükrü Ali Bey, hanedan damadı Osman Hamdi Bey, Emin Erkul, Recep Peker ve eski Şehremini Yusuf Razi (Bel) Bey gibi aydınlar da sayılabilir ${ }^{51}$.

Cemiyetin amacı Türkiye'ye büyük seyahatler tertip ederek İstanbul ile Bursa gibi önemli şehirlerdeki eserleri, Türklüğün faziletlerini yabancılara ve yabancı memleketleri de Türk vatandaşlarına tanıtmaktır. Cemiyet bu amaçları gerçekleştirmek için Avrupa, Asya, Afrika ve Amerika'dan Türkiye'ye büyük turist gruplarının gelmesini sağlamayı ve dünyanın pek çok ülkesindeki turizm cemiyetleri ile irtibata geçmeyi planlamaktadır. Cemiyet vapur ve trenle gezi programı yapan şirketlerle irtibata geçilerek Türkiye'nin de bu gezi programlarına alınmasını, ülkeyi tanıtıcı eserlerin gelen yabancıların dillerinde hazırlanmasını, eski eser ve binaların ziyareti sırasında konunun uzmanı kişilerin refakatinde ziyaretler yapılmasını, hedeflemektedir ${ }^{52}$.

${ }^{48}$ GÜLERSOY, "Reşit Saffet Atabinen'i Anma", s. 3.

${ }^{49}$ Türk Seyyahin Cemiyeti Nizamname-i Esasisi, s. 1-2, 8 (Bkz. 1.Ek); "T.T.O.K. ve Çelik Gülersoy", Çelik Gülersoy Anısına, Türkiye Turing ve Otomobil Kurumu Yayını, İstanbul 2004, s. 18; GÜLERSOY, "Reșit Saffet Atabinen'i Anma", s. 3.

${ }^{50}$ GUULERSOY, "Reşit Saffet Atabinen'i Anma", s. 3.

51 "Türkiye Turing ve Otomobil Kurumu (TTOK)", Dünden Bugüne İstanbul Ansiklopedisi, (Nuri Akbayır vd.), C. 7, Kültür Bakanlığı ve Tarih Vakfı ortak yayını, İstanbul 1994, s. 316-317; Türk Seyyahin Cemiyeti Nizamname-i Esasisi, s. 3; Türkiye Turing ve Otomobil Kurumu 30'uncu Yıl Dönümü, s. 3; bu konuda ayrica bkz Gürsoy ŞAHIN, "Atatürk Döneminde Batı'daki Olumsuz Türk ve Türkiye İmajını Düzeltme Çabaları ve Türk Seyyahin Cemiyeti'nin Bu Konudaki Çalışmaları", Afyon Kocatepe Üniversitesi Sosyal Bilimler Dergisi, Doğumunun 125. Yllında Atatürk Özel Saytst, C. VIII, S. 3, (Aralık 2006), ss.137-159.

${ }^{52}$ Türk Seyyahin Cemiyeti Nizamname-i Esasisi, s. 2-8. 
Atabinen ve arkadaşları 1923 senesinden 1926 yılına kadar çalışarak cemiyetin amaçlarını gerçekleştirmek için bilgi toplamışlar ve Avrupa'daki bu türden cemiyetlerin teşkilatlarını ve faaliyet tarzlarını öğrenerek bu işi gerçekleştirebilmek için ihtiyaç duyulan araştırmayı bitirdikten sonra uygulamaya ancak 1926 senesinde geçebilmişlerdir. Turing Cemiyeti Türkiye'nin turizm ve otomobil konulu alanlarında ulusal ve amatör organizatör olarak çalışmıştır. Turing Cemiyeti, 1930 yılında kamu yararına çalışır kurum olarak tanınmış, gümrük ve trafik mevzuatı ile de, özel yetkiler ve görevler almıştır.

\section{b) Türkiye Turing ve Otomobil Kurumunun Faaliyetleri}

Kurumun turizm adına ilk yaptığ 1 işlerden birisi turistlerin ilk temas ettikleri kayıkçılar, hamallar, otomobilcilerin dağınık ve düzensiz hallerini düzenlemek olmuştur. İlk dönemlerde rıhtıma çıkan bir yolcudan, yolcu eşyasından ne ücret alınacağı belli değildi. Cemiyetin teşebbüs ve ricaları ile İstanbul Belediyesi tarafından göz önüne alınıp önce vapurlar ile gelen turistler, kayıkçıların rahatsızlık vermelerinden kurtarılarak bunların Şirketi Hayriye ve Akay'ın muntazam küçük deniz vasıtaları ile açıkta demirleyen vapurlardan alınmaları uygulamaya konulmuş, yolcu eşyası taşıyan hamallar, arabacılar için tarifeler yapılarak gümrüklere ve uygun yerlere asılmıştır. Hatta o zamanlar hamallar için bir üniforma ve başlık kabul olunarak, diğer memleketlerde olduğu gibi hamallara giydirilmiştir ${ }^{53}$.

O dönemlerde özellikle tercümanlık büsbütün Türklere düşman olan bazı Levantenlerle azınlıkların eline geçmiş bir durumdaydı. Çoğunlukla bilgisiz olan bu tercümanlar beraber gezdikleri bütün yabancılara Türkler aleyhinde akla hayale gelmeyen uydurma hikâyeler anlatmakta idiler. Memleket için pek muzır olan bu propagandacılar Turing Cemiyetinin teşebbüsü ve fiilen hizmeti, belediyenin onayı ve yardımı ile tamamen ortadan kaldırılmıştır. Tercümanlar için belediyece kurslar açılarak kurumun arkeoloji uzmanları tarafından verilen teorik ve uygulamalı derslerle yeniden tercümanlar yetiştirilmiştir. Bu tercümanlarla kondüktör sınıfları ayrılarak bunların vazifeleri, ücretleri tayin ve tespit ettirilmiş, imtihanlar ile yeterliliğini ispat edemeyen tercümanların yabancılarla teması yasaklanmıştır. Yine Levantenlerin elinde kalmış olan turist seyahat acenteliklerinin de Reşit Saffet Bey'in belediye ile ortaklaşa çalışmaları sayesinde Türk vatandaşların eline geçmesi sağlanmıştır. Cemiyet, bu teşkilatın başında daima tarafsız bir düzenleyici vaziyetinde kalmış ve bu acentelerin turizmin gelişmesi için yaptıkları müracaatları ait olduğu makamlara bildirmiştir ${ }^{54}$.

${ }^{53}$ Türkiye Turing Klöbü Ne Yaptl, (1925-1935), s, 6.

${ }^{54}$ Türkiye Turing Klöbü Ne Yaptl, (1925-1935), s, 7; Türkiye Turing ve Otomobil Kurumu, 1923-1973, s. 13 . 
Kurumun turistlerle ilgili düzenlemelerinden bir diğeri de vize işlemleri ile ilgili olanıdır. İstanbul'a gelen yabancılar Türkiye Cumhuriyeti konsolosluklarının vizelerini kolaylıkla alamıyorlardı. Bu da konsoloslukların nerelerde olduğu yabancılarca bilinmediğinden ileri gelmekte idi. Bundan dolayı turistler zor durumda kalmakta ve polisler ise gereksiz yere fazla mesai yapmaktaydılar. Cemiyet, bu hususta Dışişleri Bakanlığ1 ile yazışmış, bütün konsoloslukların adreslerini tespit ettirmiştir. Ayrıca turist pasaportlarının vizesi, turistlerin Türkiye'de bulundukları zamanlarda bilmeleri gereken nizamnamelerin hükümleri çeşitli dillerde sirküler bastırılarak bütün elçilik, konsolosluk, turizm cemiyetlerine ve şimendifer idarelerine Cemiyet tarafından gönderilmiştir. O zamandan beri yabancılar vizeleri tamam olarak Türkiye'ye gelmeye başlamışlardır. Keza grup halinde gelen turistlerin Türkiye'nin limanlarına geldikten sonra vize muamelesi için saatlerce bekletilmemesi için bu uygulamanın polis müdürlüğünce Çanakkale'ye gönderilen polis memurları vasıtası ile yaptırılması kabul edilmiştir ${ }^{55}$.

Bu turistlere İstanbul'dan önce uğradıkları memleketlerde düşmanlık ve rekabet yüzünden yapılan olumsuz propagandaların düzeltilmesi ve bunlara Türkiye ve Türkler hakkında doğru bilgiler verilmesi için cemiyet üyelerinden bazıları Çanakkale'ye gönderilerek vapur İstanbul'a ulaşıncaya kadar Türkiye idaresi ve Türklerin gerçek yüzü hakkında çeşitli dillerde konferans verilmesi kararlaştırılmıştır. Daha önceleri Türkiye'ye transit olarak gelen turistlerin pasaportları ellerinden alınır ve bundan dolayı turistler birçok zorluklar görürdü. Kulübün teşebbüsü ile bundan vazgeçilmiş, İstanbul'dan transit olarak geçen yabancıların Türk vizesine lüzum olmaksızın çıkıp şehri gezmelerine izin verilmiştir. Kruvaziyerlerle gelen turistler de transit sayılarak bunlarin da vizesiz gelmelerine izin verilmiştir. Türkiye'ye sağlık veya hava değişimi için gelecek olanlardan vize harcı alınmaması için çaba gösterilmiş, yabancıların pasaport ve vize muameleleri ile ilgili şikâyetleri, sürekli olarak İçişleri Bakanlığı'na veya gerekli mercilere bildirilerek gerekli uygulama önceden yapılmaya çalışılmıştır ${ }^{56}$.

Türkiye'ye gelen turistler arasında yüksek düzeyde olanlar cemiyet tarafından genellikle haber alınarak bunlara gümrüklerde kolaylık yapılması mektupla veya telefonla rica, şikâyetleri olanların şikâyetlerinin incelenmesi ve bunlardan haklı olanların ilgili makamlara bildirilmesi söz konusu olmuştur. Gelen turistlerin şahsi eşyaları arasında kontenjana tabi eşya dahi olsa bunların gümrük vergisi 50 lirayı aşmamak şartı ile ithallerine yine bu kişilerin kişisel ve açık şişelerde bulunan kolonya, içki ve lavanta gibi

\footnotetext{
${ }^{55}$ Türkiye Turing Klöbü Ne Yaptl, (1925-1935), s, 8; Türkiye Turing ve Otomobil Kurumu 30'uncu Yıl Dönümü, s. 6; Türkiye Turing ve Otomobil Kurumu, 1923-1973, s. 13.

${ }^{56}$ Türkiye Turing Klöbü Ne Yapti, (1925-1935), s, 9.
} 
eşyalardan gümrük alınmamasına dair karar Reşit Saffet Bey ve cemiyetin teşebbüsleri ile alınmıştır. Gümrüklerde yabancı turistlere önceki dönemlerden daha nazikçe muamele yapılmaya başlanmıştır.

Turizm malzemesi ile Turizm propagandasına yarayan şeylerin gümrüklerden muafen sokulması için yine Turing Kurumu'nun teşebbüsü ile bir kanun çıkarılmıştır ${ }^{57}$. Son olarak Ekonomi Bakanlığı'nda toplanan bakanlıklar arası Turizm Komisyonu'na Cemiyet tarafindan verilen raporda arz edilen usuller ve tedbirler bu Komisyonca tamamen kabul edilmiştir. Bunları tatbik edecek memurların iyi seçilmesine özen gösterilmiş, turistlere ve yolculara ait gümrük muamelelerinin Avrupa'nın gümrük muamelelerine paralelliği sağlanmaya çalışılmıştır.

Türkiye'ye gelen turistler için bir takım finansal kolaylıklar da sağlanmıştır. Tatil zamanlarında gelen yabancıların para harcamaları için Vagon-Li İdaresi ile bazı seyahat acentelerine ve otellere para bozma yetkisi verilmiştir. Yabancıların aldatılmamaları için gelen turist vapurlarına para bozmak için Merkez Bankasından memur gönderilmesi kararlaştırılmıştır. Cemiyetin ve Reşit Saffet Bey'in çabaları ile Türkiye'yi ziyaret ve tedavi gibi sebeplerle gelen yabancılardan Tahsil Şubelerinde ilişiği olmadığına dair vesika istenilmemesine karar verilmiştir. Yine daha önceki dönemlerde yabancıların yanlarında bulunan 25 Türk lirasından fazlası Gümrüğe bırakılmakta ve bazen giderken bunu alamamakta idiler. Bu mesele de belirli bir usule bağlanmıştır.

Turist vapurlarının Türkiye'de tabi bulundukları vergi, başka memleketlere oranla daha fazla olmasından dolayı Akdeniz'de dolaşan vapurlardan ancak \% 20 si Türk limanlarına gelmekte idi. Cemiyetin teşebbüsleri ile hükümetçe bu vapurlarla yatlardan ve ilmi maksada hizmet için kullanılan gemilerden alınan vergiden bir kısmının tamamen muaf tutulması ve bir kısmının da \% 50 indirimi için hükümete bir kanun layihası sunulmuştur. Keza Turing Kurumu'nun teşebbüsleri ile Bayındırlık Bakanlığınca toplu olarak gelecek yolcular ve Turistler için kayıtsız şartsız Devlet Demiryollarında \% 50 indirim kabul edilmiştir ${ }^{58}$.

Turist gemileri ile yatlardan Karadeniz Boğazı'ndan çıktıkları zaman ton başına 5 kuruş tahlisiye vergisi alınmakta idi. Bu miktar tonajları fazla olan seyyah vapurları için ehemmiyetli bir miktara ulaştığından birçokları Boğaza gidememekte idi. Bu resmin alınmaması hakkında karar onaylanmıştır. Cemiyetin teşebbüsleri üzerine Türk Seyahat Acentelerinin yabancı memleketlere seyahat tertip edebilmeleri için döviz izni verilmiştir. Turing'in teşebbüsleri ile en güzel bahçesi olan Devlet Demiryolu

${ }^{57}$ Düstur, 3. Tertip, (Teşrinisani 1933-Teşrinisani 1934), C. 15, Başvekâlet Matbaası, Ankara 1934, s. 116.

${ }_{58}^{5}$ Türkiye Turing Klöbü Ne Yaptl, (1925-1935), s, 11. 
istasyonuna idarece mükâfat verilmesine karar verilmiş ve bu karar uygulanmıştır.

Yine turistlerin Türkiye'de rahatça gezebilmeleri için yol işaretlerinin bir an evvel ülkenin yollarına da konulması hususundaki teşebbüsler sonucunda belediyece dikkate alınarak İstanbul'un bazı iç ve dış caddeleri ve yollarına bu işaretler konulmuştur. Türkiye'de beş on gün kalmak için gelen turistlere bazı maliye memurları tarafından tedrisat vergisi ve pul parası istenilmekte idi. Bu hususta kurumun dilekleri kabul edilerek Türkiye'de ikamet tezkeresi alarak altı aydan az bir süre oturanlardan hiç bir vergi alınmaması yoluna gidilmiştir. İllerdeki bazı iyi otellere gerek otellerin tertibatı, gerek turistlerin bu otellerde kabul tarzları hakkında tavsiyelerde bulunularak sahiplerinin arzuları ile Turing adı ve işaretli plakalar da verilmiştir ${ }^{59}$.

Bunların yanında yerli malların bazı fırsatçılar tarafından yüksek fiyatlarla satılarak turistlerin aldatıldığı görülerek, Turing Kurumu'nun çabaları ve İstanbul Belediyesi tarafından Sandal Bedesteninde yalnız yerli mallara mahsus bir sergi açılmış ve burada satılan eşyaya sabit ve gerçek fiyatlar koydurularak turistlerin aldatılması engellenmiştir. Tek başına veya grup halinde gelen seyyahlar arasında gazeteci, yazar, mebus, önde gelen önemli kişilerin bulunduğu haber alınınca cemiyet tarafından bu kișiler karşılanmakta ve kendilerine ikramda bulunulmaktadır. Yine yabancı yüksek okullar veya üniversite öğrencisi geldikçe Darülfünun Emanetine haber verilmiş ve bazen bunlara Turing Kulübü tarafından ikramlarda bulunulmuştur. Keza yabancı turistlerin surlar üzerinden şehrin genel manzaralarını görebilmeleri için Ayvansaray civarındaki en yüksek kısma Reşit Saffet Bey ve cemiyetin ricaları ile belediyece demirden güzel bir merdiven yaptırılmıştır ${ }^{60}$.

Cemiyet, Avrupa'daki birçok memlekette olduğu gibi Türkiye Büyük Millet Meclisi'nde bir "Parlömanter Turizm Grubu" teşkiline ön ayak olmuş, bu grubun Milletlerarası Parlamentolar Turizm Konferansına bağlanmasına ve Türkiye Talebe Turizm Federasyonu'nun teşkiline aracı olunmuştur $^{61}$. Yukarıda sayılan çalışmaların yanında Türkiye'ye en çok para bırakanların otomobiller ile seyahat edenler olduğunu dikkate alınarak uluslararası seyahatleri kolaylaştırmak için, Reşit Saffet Bey ve Cemiyet, önemli işler başarmıştır. Otomobilli turistleri gittikleri ülkelere girerken gümrük parası depozito ödeyerek, çıkarken almak ve bunu her memlekette tekrar etmek zorluğundan kurtarmak için, diğer memleketlerde eski zamanlardan beri Triptik denilen belge geçtiği halde, Türkiye'de o döneme

\footnotetext{
${ }^{59}$ Türkiye Turing Klöbü Ne Yaptı, (1925-1935), s, 12.

${ }^{60}$ Türkiye Turing Klöbü Ne Yaptı, (1925-1935), s, 13.

${ }^{61}$ Türkiye Turing ve Otomobil Kurumu 30'uncu Yll Dönümü, s. 5.
} 
kadar uygulanmakta idi. Cemiyetin teşebbüsü ile Gümrük Kanunu'nun bu konu ile ilgili maddesi değiştirilerek 1 Mayıs 1930 tarihinde 1605 sayılı kanunla, Triptik, Türk gümrüklerinde de nakit yerine kabul olunmaya başlanmıştır ${ }^{62}$. Böylece Türkiye'ye otomobilli turistler daha çok gelmeye başlamıştır.

Triptiğin uluslararası seyahatlerde verdiği kolaylık o dönemlerde yeterli görülmediğinden, turizm için bütün memleketlerde geçer tek ve uluslararası bir gümrük belgesi olan "Gümrüklerden Geçiş Karnesi" kurumun teşebbüsleri ile kabul edilmiştir. Sadece Gümrükler Geçiş Karnesi'nin kabulünden dolayı gereken pasaport vizeleri sadece Türkiye'ye girerken ve çıkarken yapılmış aradaki vizeler hafifletilmiştir. Böylece ülkede otomobilli turistlerin daha çok sayıda gelmesinin bu suretle önemli ekonomik faydalar elde edilmesinin önü açılmıştır.

Edirne'den İstanbul'a gelen yol üzerinde yasak bölgeler bulunmakta olup yabancıların bu mıntıkayı geçmesi söz konusu değildi. Daha önceki dönemlerde Edirne'ye kadar gelen bir yolcu orada otomobilini trene yükletmek mecburiyetinde idi. Kurumun ve Reşit Saffet Bey'in teşebbüsleri ile yabancıların bu bölgelerden Jandarma eşliğinde geçmelerine izin verilmiştir. Otomobillerin uluslararası seyrü sefer trafiği düzenleyen 1926 Paris Antlaşması da Türkiye Cumhuriyeti hükümetince kabul olunduğundan, uluslararası ehliyetleri düzenleme yetkisi de 1930 yılında Turing Cemiyetine verilmiştir. Yine uluslararası otomobil işaret levhaları da Türkiye'de resmen geçer olmuştur ${ }^{63}$.

Türkiye'nin coğrafi durumu nedeniyle o dönemde, Uluslararası Turizm Birliği'nin kararı ile Edirne-İstanbul yolu Avrupa'yı Asya ve Afrika'ya bağlayan transit yolun bir kısmını teşkil etmiştir. Cemiyetin girişim ve çalışmaları sonucunda yolun bir kısım köprüleri ve bazı yerleri tamir edilmiştir. Cemiyet, İstanbul'u bölgelere ayırarak "Adaları Güzelleștirme Cemiyeti" adı ile yeni bir oluşum meydana getirmiștir. Ayrıca adaların su meselesi yine cemiyetin teşebbüsü ve kaymakamın yardımı ile çözülmüştür.

$\mathrm{O}$ dönemlerde büyük bir rağbet kazanan kayak sporu için durumu çok müsait olan Uludağ'dan istifade edilmek için Turing Kurumu, İçişleri Bakanlığına ve Genelkurmay Başkanlığı'na müracaat etmiş ve rapor sunularak Uludağ'da basit de olsa bir tesis oluşturmak için bu sporun uygulanmasına başlanmıştır. Bu teşebbüs bugün Uludağ ve Bursa'da turizmin gelişmesinde Reşit Saffet ve Turing Kurumunun ne derece etkili olduğunu göstermektedir.

62 Düstur, 3. Tertip, (14 Teşrinisani 1929-15 Teşrinisani 1930), C. 11, Başvekâlet Müdevvenat Matbaası, Ankara 1930, s. 382.

${ }_{63}$ Türkiye Turing ve Otomobil Klöbü'nün Tadil Olunmuş Nizamnamesi, s. 13; Türkiye'ye Bir Işıktı Turing 1977-1993 (1-Doğum ve Emekleme), s. 8-9; [y-y], "Türkiye Turing ve Otomobil Kurumu (TTOK)", s. 317. 
Yine bu dönemlerde Türkiye'de ufak geziler tertip edilerek Cemiyetin teklifi üzerine Devlet Demiryolları'nın gerçekleştirdiği Sapanca gezileri halkın büyük beğenisini kazanmıs ve o civar halkına ekonomik olarak büyük faydalar sağlamıștır. İzmir ve Ege bölgesinde yapılan gezintiler de yine halk tarafından ilgiyle izlenmiștir. Türkiye'de turizmin hakkı ile anlaşılması için cemiyetin yayınları vasıtası ile sürekli bir turizm akımı meydana getirilmeye çalışılmış ve gazetelerin başyazarları ile ilişkiler kurularak bu anlayış sürdürülmeye çalışılmıştır. İdari meseleler için turizmin genişlemesine engel olacak etkenleri ortaya koyan Ekonomi Bakanlı̆̆ı'nın incelemeleri ve Turing Kurumu'nun tecrübelerini ihtiva eden teklifleri yukarıda bahsi geçen Bakanlıklar arası komisyonunca yerinde görülmüş ve kabul olunarak Komisyonun Genel Heyetine sunulmuştur. Türkiye'de "Tourisme Receptif" bakımından vücuda getirilmesi lazım gelen yenilikleri ve turizm bakımından yapılacak düzenlemeleri gösteren bir turizm programı yapılarak Ekonomi Bakanlığına sunulmuştur.

Yine Atabinen'in ve kurumun çalışmaları ile turistler tarafından ziyaret edilen camiler ile diğer eski eserlerde görülen eksiklikler ve kusurlar göz önünde bulundurularak bunlardan İstanbul ve diğer şehirlerde bulunan 800 'ü aşkın tarihi eserin durumları yazı ve fotoğraflarla tespit edilerek, bunların iyileştirilmesi için ilgili makamlara müracaat edilmiş, bu teşebbüsler vakıflar nezdinde sürekli ilgiyle karşılanmıştır. Bu arada bu eserlerden 34'ü kurum tarafından tamir ettirilmiştir ${ }^{64}$. Tarihi türbelerin müzelere bağlanması sağlanmıştır. Bu dönemde Ankara'da eski eserleri (âsâr-1 atîkayı) muhafaza komisyonu teşekkül ettirilmiş ve turizm meselesi 1930 yılında Ekonomi Bakanlığı'nın programına girmiştir. Yine 1930 senesinde İçişleri Bakanlığı'na bağlı Emniyet İşleri Genel Müdürlüğü'ne bağlı bir Turizm Müşavirliği kurulmuş ve aynı zamanlarda Bursa'da bir turizm şubesi açılmıştır ${ }^{65}$.

\section{c) Reșit Saffet Bey'in Kișisel Faaliyetleri}

Turing Kurumu dişında Reșit Saffet'in kişisel olarak da son derece önemli çalışmaları olmuştur. Mesela o, 1930 yılında, Atina'da toplanan Balkan Birliği Konferansına Türk Hükümeti delegesi olarak katılmış ve kendisi orada "Balkan Turizm İttihadı" başkanlığına seçilmiștir ve İstanbul bu birliğin merkezi olmuştur ${ }^{66}$. Reşit Saffet Bey'in ve Turing Kurumunun turistleri Türkiye'ye gelmeye teşvik için acenteler, konsolosluklar, Turing ve otomobil kulüpleri, seyahat acenteleri, fahri temsilciler ve şubeler vasıtası ile dağıtılan ve 450.000'i aşan Fransızca, İngilizce, Almanca, İtalyanca, Rumca, ve Arapça prospektüsler, afişler Türkiye hakkında konferans vermek,

${ }^{64}$ Türkiye Turing ve Otomobil Kurumu 30'uncu Yll Dönümü, s. 8.

${ }^{65}$ Türkiye Turing Klöbü Ne Yaptı, (1925-1935), s. 17.

${ }^{66}$ Türkiye Turing ve Otomobil Kurumu, 1923-1973, s. 23-24. 
mecmua, risale, takvim neşretmek, makale yazmak veya prospektüs yapmak isteyenlere memleketin güzelliklerini, abidelerini, eski eserlerini gösteren fotoğraflar gönderdiği anlaşılmaktadır. Bu fotoğrafların Weinberg'e birkaç yüz adet olarak hazırlatıldığı ve arkasına bazı bilgiler ve şehir planı konularak hazırlandı $\breve{g}_{1}{ }^{67}$ ve Türkiye'ye seyahat şartlarını ve faydalı bilgileri içeren el ilanları ve sirkülerler gönderildiği anlaşılmaktadır ${ }^{68}$.

Keza uluslararası birçok sergiye Türkiye ile ilgili propaganda afişleri, yayın ve memleketin fotoğraflarını göndermek sureti ile iştirak edilmiștir. Uluslararası Turizm ve Otomobil teşekküllerinin senelik kongre veya idare meclisleri toplantılarında bulunulmuş, Mısır'da propaganda yapmak için Kahire'nin işlek bir yerinde idare bürosu bulunan bir delegelik de kurulmuştur. Cemiyete bağlı olarak İstanbul'da kurulan çeşitli komiteler ve Avrupa'nın bazı memleketlerinde olușturulan dış komiteler aracılığıyla Türkiye hakkında tanıtım yapılmış, Reşit Saffet Bey ise yabancı memleketlerde Türkiye'ye ve Türk Turizmine dair birçok konferans vermiştir.

Bu dönemde Reşit Saffet Bey'in en önemli çalıșması Türkiye'nin yeni üye olduğu Uluslararası Turizm Birliğinin (AIT-Alliance Internationale de Tourisme) İstanbul'da toplanmasının sağlanması olmuştur. Bu amaçla Dolmabahçe Sarayı tarihinde ilk kez turizme açılmıştır. Bu olağanüstü olayın bir ucundaki başarı, Kurum Başkanı Reşit Saffet Atabinen'e diğeri de Dolmabahçe Sarayını tören için açtıran ise M. Kemal Atatürk'e aittir ${ }^{69}$. Kongre Atatürk'ün yüksek teveccühleri ile çalışmalarına başlamıştır. Bu durum yabancı konukların son derece hoşuna gitmiş hatta şimdiye kadar Türkiye'de yapıldığı gibi gösterişli bir Turing Kulüpleri toplantısı yapılmadığını ifade etmişlerdir. 24 Turing Kulüp ve Turizm kuruluşu ortaklaşa turizmin gelişmesi için neler yapılması gerektiğini tartışmışlardır ${ }^{70}$.

Kongreyi açan İçişleri Bakanı Şükrü Kaya, yaptığı konuşmada Türkiye'nin turizm anlayışını ve politikasını açıklamıştır ${ }^{71}$. Kongre çalışmaları sonunda kabul edilen esaslara göre; yolların ıslah edilmesi, tehlikeli geçitlerin tamiri, toza karşı tedbirler alınması, sınırlarda gece ve gündüz gümrük ve polis işlerinin kolaylıkla yapılmasının temin edilmesi, belirli yerlerde oteller vücuda getirilmesi, gezilen memleketlerle ilgili risaleler hazırlanması, yol haritalarının hazırlanması ve yolların tehlikeli

${ }^{67}$ Türkiye Turing ve Otomobil Kurumu, 1923-1973, s. 23-24.

${ }^{68}$ Türkiye Turing ve Otomobil Kurumu 30'uncu Yıl Dönümü, s. 7; Türkiye Turing ve Otomobil Kuгити, 1923-1973, s. 17.

${ }^{69}$ Ertuğrul Zekai ÖKTE, Gazi Mustafa Kemal Atatürk'ün Yurtiçi Gezileri (1923-1931), Tarihi Arastırmalar Vakfı yayını, İstanbul 2000, s. 619; "T.T.O.K. ve Çelik Gülersoy", Çelik Gülersoy Anısına, Türkiye Turing ve Otomobil Kurumu Yayını, İstanbul 2004, s. 18-19.

${ }^{70} B C A, 30.10 / 80.526 .6$, s. 1 .

${ }^{71}$ Bu konusma metni Türkçe ve Fransızca olarak hazırlanmıs ve yayınlanmıștır. Bu konușma Başbakanlık Cumhuriyet Arşivinde bulunmaktadır. Bkz. BCA, 30.10/229.543.14. 
kısımlarına uluslararası trafik işaretleri konulması kararlaştırılmıştır ${ }^{72}$. Kurumun yayın organı olan Belleten Dergisi'nde bu türden yol işaretlerinin ne anlama geldiği ve trafikle ilgili önemli açıklamalar bulunmaktadır ${ }^{73}$. Aynı dönemde Türkiye'nin tanıtımı adına yurt dışında hazırlatılan ve Türkiye'ye getirilen propaganda ilanları, risaleler, duvar takvimleri, otomobil ve otel plaka ve matbu bayrakları gündüz ve geceye özel yol işaretleri, rozetler, ödül, kupa ve şiltlerinin gümrük vergisinden muaf tutulduğu anlaşılmaktadır ${ }^{74}$.

1931 yılında Reșit Saffet Atabinen'in başkanı olduğu Balkan Turizm İttihadı 25.4.1931 tarihinde İstanbul'da bir toplantı yapmıştır. Bu kongre aynı zaman Balkan Birliğinin bir bölümü olarak da görüldüğü için başta Cumhurbaşkanı Atatürk olmak üzere, Başbakan İsmet İnönü ve Dıșişleri Bakanı Tevfik Rüştü Bey başarı telgrafları göndermişlerdir ${ }^{75}$. Turing Kurumu çeşitli senelerde yabancı ülkelere giden bazı öğrenci gruplarına oradaki Turing Kulüpleri aracılığıyla yardımcı da olmuştur. Keza Boğaziçi ve Yalova hakkında propaganda yapmak için üyelerden Halil Halid Bey, Misır'a gönderilmiştir. Yine 1931 senesinde Prag'da toplanan Turizm Meclisi İdare Heyeti toplantısına Reşit Saffet Bey ve Genel Sekreter Cevdet Bey katılmışlardır ${ }^{76}$.

Turing Kurumu Turizm ve otomobil sporları bakımından dünyanın en önemli teşekkülleri olan "Uluslararası Turizm Birliğı" (Alliance Internationale de Tourisme) ile "Uluslararası Tanınmış Otomobil Kulüpleri Birliğiı" (Association Internationale des Automobile-Clubs Reconnus), "Uluslararası Turistik Propaganda Birliğı"” (Association Internationale des Organes de Propagande Touristique) ve Merkezi Turizm Meclislerinin idare meclislerine iştirak edilmiş ve kurum bu çalışmaları ile Türkiye'nin turizm açısından menfaatini müdafaa edebilecek ve bu alanda gerçekleşecek yeniliklerden zamanında haberdar olacak bir konuma gelmiştir ${ }^{77^{7}}$. Bu cemiyetlerin tamamı asla ticari ve mali bir amaç gütmeden sadece yerli ve yabancı turizmin gelişmesine hizmet etmeye çalışmıştı ${ }^{78}$.

Yine Reşit Saffet Bey tarafından Viyana, Milano, Roma, Floransa ve Bükreş'te Türkiye'de turizme ait bir dizi konferans verilmiştir ${ }^{79}$. Paris'te triptik rejimi ile gümrüklerden geçiş karnesi için toplanan konferansta

${ }^{72} B C A, 30.10 / 80.526 .6$, s. 9 .

${ }^{73}$ BCA, 490.01/600.77.1, numarada bulunan Türkiye Turing ve Otomobil Klöbü Belleteni, No. 26-181, (Nisan 1940), s. $15 \mathrm{vd}$.

${ }^{74}$ Düstur, 3. Tertip, (Teşrinisani 1933-Teşrinisani 1934), C. 15, Başvekâlet Matbaası, Ankara 1934, s. 116.

${ }^{75}$ Türkiye Turing ve Otomobil Kurumu, 1923-1973, s. 29-31.

${ }^{76}$ Türkiye Turing ve Otomobil Kurumu, 1923-1973, s. 32.

${ }^{n}$ Türkiye Turing Klöbü Ne Yaptt, (1925-1935), s. 18-20.

${ }^{78}$ BCA, 30.10/80.526.6, s. 2.

${ }^{79}$ Türkiye Turing ve Otomobil Kurumu, 1923-1973, s. 39 vd. 
Türkiye'yi Paris Elçiliğinde görevli bir memur temsil etmiş, Nis'te TürkFransız Komitesi kurulmuştur. Bu Komite Nis'te 14-21 Mart 1931 tarihlerinde bir "Türk Haftası" düzenleyerek bu hafta boyunca Türk eserleri ve Kızılay işlemeleri ile Türk ressamlarının resimlerini sergilemiş ve görkemli bir müsamere de vermiştir.

1931 yılında cemiyet Nis'te açılan Turizm Konferansı ile Uluslararası Turizm Merkezi Meclisi Kongresine, Kopenhag'da toplanmış olan Uluslararası Turizm Birliği senelik kongresine, Sen Rafael'de açılan turizm sergisine katılmış, Filistin'de Telaviv'de açılan Şark Panayırına da resim, afiş ve turizm malzemesi göndermiştir. Budapeşte'nin son Türk valisi olan Abdürrahman Abdi Paşa namına Macarlar tarafından yapılan abidenin 1932 senesinde yapılan açılş törenine Reşit Saffet Bey katılmış ve tarihi bir konuşma yapmıştır. Turing Cemiyeti ile "Syndicat d'Initiative de Vichy" arasında iki memleket arasında turizmin gelişmesi için bir sözleşme yapılmıștır. Bunun yanında Atina ve Sofya'ya giden üniversite ve ticaret okulu öğrencilerine ve diğer Türk sporcularına mahalli Turing teşkilatları tarafından kolaylık gösterilmesi için girişimler söz konusu olmuştur. Yine 1932 senesinde Bükreş'te Romanya Kralı'nın himayesinde toplanan Balkan Turizm Federasyonu Kongresine katılınmış, Sofya'da Türk-Bulgar, Atina'da Türk-Yunan ve Romanya'da Türk-Romen Komiteleri kurulmuştur.

Türkiye'nin eski eserlerini ve güzel manzaralarını gösteren büyük boy fotoğrafları, afişleri ve diğer turizm malzemesi 1932 senesi ilkbaharında açılan Milano, Paris Sergilerinde sergilenmiştir. Prag'da toplanan Uluslararası Turizm Birliği senelik kongresine ve ondan sonra Pește'de toplanan Uluslararası Merkezi Turizm Meclisinin senelik kongresine ve Peşte'de bu münasebetle bir Türk-Macar Turizm Komitesi, İtalya'da ise bir Türk-İtalyan Turizm Heyeti kurulmuştur. Tüm çalışmalarda Reşit Saffet Bey'in üstün gayretleri söz konudur ${ }^{80}$.

Reșit Saffet Atabinen'in Türkiye Turing ve Otomobil Kulübünün Başbakanlığa bağlanması ve bu şekilde faaliyet göstermesi ile ilgili olarak 15.12.1932 tarihinde bir talebi söz konudur. Turing Kulübünün bu isteğine İçişleri Bakanı Şükrü Kaya'nın pek destek vermediği ve 18.3.1933 tarihli cevapta bu isteğe lüzum olmadığı, kulübün Dâhiliye Vekâleti ile muhabere eder bir cemiyet halinde kalmasının daha uygun olacağ ifade edilmiştir $^{81}$.

1933 senesi Şubat ayında Mısır'ın Kahire şehrinde toplanan Uluslararası Turizm Birliği kongresine gidilmiş, Kahire ve İskenderiye'de bir Türk-Mısır Komitesi kurulmuştur. Daha sonra İstanbul'a Turing Cemiyetinin ve "Muhadenet" Gazetesi sahibi Remzi Bey'in aracılığı ile Mısır'ın en tanınmış doktorları, gazetecileri ve aydınlarından oluşan bir grup

${ }^{80}$ Türkiye Turing Klöbü Ne Yaptl, (1925-1935), s. 21-22.

${ }^{81} B C A, 30.10 .0 .0 / 80.526 .12$, s. 1-4. 
Türkiye'de misafir edilmiş, bu kişiler Türkiye Cumhuriyeti Hükümeti'nin misafiri olarak ağırlanmışlar, dönüşlerinde Mısır gazetelerinde Türkiye'ye seyahati teşvik eden birçok makaleler yazmışlardır. Kurumun Ekonomi Bakanlığına müracaatı üzerine Kahire'deki İş Bankasının "Publicite" kısmında turizm malzemesinin sergilenmesi için bir memur görevlendirilmiştir.

1934 senesinde Peşte'ye bir seyahat düzenlenmiştir ki bu seyahat yabancı bir ülkeye düzenlenen ilk seyahattir. Yine cemiyet Haziran'da Lahey'de toplanan Turizm Birliği İdare Meclisi toplantısına ve Roma'da toplanan Turizm Kongresine katılmıştır. Ayrıca Haziran'da Paris'te toplanan Merkezi Turizm Meclisinde ve bunun ardından Londra'da toplanan Uluslararası Turizm Birliği'nin Kongresinde de (A.İ.T.) bulunmuştur. Türkiye Cumhuriyeti'nin son on sene zarfında çeşitli alanlarda meydana getirdiği gelişmeyi gösteren ve Anadolu Ajansı tarafından Fransızca olarak bastırılan eseri, bazı yabancı gazetelere ve Türkiye'nin ilerlemesi hakkında eser yazmak isteyenlere ve bazı yabancılara göndermiştir ${ }^{82}$.

Elbette tüm bu işleri Reşit Saffet Bey tek başına yapmamıştır. Ancak onun gerek manevi gerekse maddi olarak son derece büyük katkıları ve şahsi bağlantıları Turing Kurumu'nun bu noktaya gelmesini sağlamıştır. Hatta yeri gelmişken şunu da ifade etmek gerekir ki Cemiyetin Galata'daki Adalet Hanındaki kirasını ilk beş altı sene Reşit Saffet Bey bizzat karşılamıştır ${ }^{83}$.

Onun tarafından kurulan Cemiyet ve üyelerin de gayretli faaliyetleri söz konusudur. Ancak bu işlerde esas başarı ona aittir. Reşit Saffet Bey, Türkiye'de uzun yıllar turizm, kültür ve teknik alanlarda, son derece önemli çalışmalara imza atmış, kurduğu Turing Cemiyeti sayesinde Türkiye'nin ilk turistik rehberleri yetiştirilmeye çalışılmış, ilk karayolu haritası, ilk afişlerinin bastırılması, ilk yabancı dil kurslarının açılması, ilk tercüman rehber sınavları yapılması, ilk turizm incelemeleri yazdırılmış ve yayınlanmış, turizm kongre ve konferansları düzenlenmiş, devlet mekanizmasının, mevzuatın ve metotların, turizm ihtiyaçları ile yeni baştan düşünülmesinin yolu açılmaya çalışılmıştır ${ }^{84}$.

Yeri gelmişken şunu da eklemek gerekmektedir ki Reşit Saffet Beyin 1930'lu yıllarda teklif ettiği Türkiye'yi ve Türkleri yabancı ülkelerde tanıtma propaganda yöntemleri kendisinin bu görüşleri açıklamasından yaklaşık otuz yıl sonra devlet adamları tarafından dillendirilmeye başlanmıştır. Mesela 1967 yılında Amerika'da Türkiye'nin tanıtımı adına yapılacak çalışmalar sıralanırken adı geçen ülkede bir büro kurulması, başına bilgili ve yabancı

${ }_{82}^{82}$ Türkiye Turing Klöbü Ne Yaptı, (1925-1935), s. 23 vd

${ }^{83}$ BCA, 03.01./17.95.10, s. 1 .

${ }^{84}$ Türkiye'ye Bir Işıktı Turing 1977-1993 (1- Doğum ve Emekleme), s. 8; keza GÜLERSOY, "Reşit Saffet Atabinen'i Anma", s. 6. 
dili son derce iyi olan bir kişinin getirilmesi, gazetecilerle temasın arttırılması, propaganda broşürlerinin hazırlanması, Türkiye ile ilgili resimlerin hazırlanması, televizyonlarda tanıtıcı filmler hazırlatılması ve her türlü imkânı ve kadroyu propaganda için kullanma gerekliliğinden bahsedilmektedir ${ }^{85}$.

\section{d) Kurumun Türk Turizmine Katkılart}

Bu dönemde İstanbul ve Türkiye'ye gelen turist sayısı kaynaklardan elde edilen bilgilere göre 1922 'de $5.000,1924$ 'de $17.000,1925$ 'de 40.000 , 1930 'da $45.500,1934$ 'de $80.000,1936$ 'da 84.373 ' $^{\prime}$ ir $^{86}$. II. Dünya Savaş1 yıllarında ise genel olarak turist sayısı oldukça azalacaktır ${ }^{87}$. Dünya genelindeki olumsuz hava Türkiye'yi de etkileyecek ve turizmi baltalayacaktır $^{88}$. Savaştan sonraki yillarda da Türkiye'ye gelen turist sayısında önemli bir azalma görülmektedir. Mesela savaştan dört yıl sonra 1949 'da bile Türkiye'ye gelen yabancı sayısının 19.500 ve 1950 'de 28.625 olduğu anlaşılmaktadır ${ }^{89}$.

Reşit Saffet Bey'in, İstanbul'un tarihi kimliğinin korunması ve turizme kazandırılması konusunda büyük çabaları söz konusu olmuştur. Mesela 1941 yılında Turing Kurumu içinde ve kadrosu çerçevesinde Meşrutiyet döneminde Fransız elçisinin eşi Mme Bompard'ın gayreti ile 1911'de kurulan "Istanbul Muhipleri Cemiyetine" "İstanbul'u Sevenler Grubu",90 adı ile yeniden etkinlik kazandırarak harabeye dönüșen eski dönemlerden kalan abide yapıtların onarımını sağlamasıdır ${ }^{91}$. O, Turing kurumunun Belleteninde eski eserlerinin tanıtılmasına özel bir önem vermiştir. 1945-46 yıllarında Arkeoloji müzesinde "Eski Eserler Encümeni" üyeliği yapmıştır. 1948 İstanbul'daki Osmanlı eserlerine ilgi duyan Reşit Saffet Bey, bu konuyu içeren bir kitaplığın kurulmasını arzu etmiş ve 1848 yılında İstanbul Vakıflar Başmüdürlüğü'nden Galata Eski Gümrük Sokağı'ndaki Sıbyan Mektebini kiralayarak işe başlamıştır. Turing Kurumu kısıtlı imkânları ile Sıbyan Mektebini onarmış ve bu dönemde Çelik Gülersoy da kitaplığı düzenlemekle görevlendirilmiştir.

Kurum aynı anlayış ve gayretle çalışmalarına devam etmektedir. Örnek olması açısından bu yıllarda bastırılıp dağıtılan broşürlerin miktarını bildirmek önemlidir. 1951 'de $215.000,1952$ 'de bunlara ilaveten 162.000 ,

${ }^{85}$ BCA, 30.1.0.0/64.396.3, s. 4-6.

${ }^{86}$ Türkiye Turing ve Otomobil Kurumu, 1923-1973, s. 17, 26, 33, 53

87 Arslan YÜZGÜN, "Türkiye Turizminin Boyutları", Cumhuriyet Dönemi Türkiye Ansiklopedisi, C. 9, (yay. haz. Mücteba Anğ vd.), İletişim yay., İstanbul 1983, s. 2566.

${ }_{88}$ BCA, 490.01/600.77.1, numarada bulunan Türkiye Turing ve Otomobil Klöbü Belleteni, No. 26-181, (Nisan 1940), s. 4.

${ }^{89}$ YÜZGÜN, a.g.m., s. 2566.

"Semavi EYICE, "Resid Saffet Atabinen (1884-1965)", Türkive Turing ve Otomobil Kurumu Belleteni, 276-279, (Ocak-Nisan 1965), s. 5.

"ÖZTÜRK, a.g.e., s. 401; EYİCE, a.g.m., s. 5. 
1953'de 252.000, Mayıs 1954 ile Mayıs 1956 yılları arasında ise Türkçe, Fransızca, Almanca, İspanyolca olmak üzere 58 çeşit ve 1.004 .300 adet broşür basılmış ve dağıtılmıştır ${ }^{92}$.

1950'li yıllarda kurumun Atatürk döneminden gelen prestiji devam etmektedir. Bu dönemde bizzat Celal Bayar ve Adnan Menderes bu prestijin sürdürücüsü olmuşlar ve Türkiye Turing ve Otomobil Kurumu'na desteklerini sürdürmüşlerdir. Kurumun 1957 yılı genel kurul raporuna göre Cumhurbaşkanı Celal Bayar, TBMM'i Başkanı Refik Koraltan ve Başbakan Adnan Menderes'in hâmi azalardan oldukları anlaşılmaktadır ${ }^{93}$. Ancak Cihat Baban ve Nadir Nadi gibi isimler "Türkiye Turizm Kurumu" adında yeni bir kurum kurmuşlardır. Fakat birkaç yıl sonra bu kurum bir takım skandallarla önem kaybetmiştir. Bunun ardından Ord. Prof. Dr. Sıddık Sami Onar gibi itibarlı kurucular Türkiye Turing ve Otomobil Kurumu'na geçmişlerdir. Reşit Saffet Atabinen'in 1965 yılında vefat ettikten sonra kurum Çelik Gülersoy ile yoluna devam etmiştir ${ }^{94}$.

\section{SONUÇ}

Reşit Saffet Atabinen, 1884-1965 yılları arasında yaşamış, Osmanlının son yıllarını, Meşrutiyet Dönemini, I. Dünya savaşını, Millı̂ Mücadele Dönemini ve Cumhuriyetin ilk yıllarını görmüş gerçek bir entelektüel ve Türk aydınıdır. Onun diplomatlık, tarihçilik ve yazarlık gibi özelliklerinin yanında Türkiye'nin gerek Avrupa'da gerekse Doğu ülkelerinde tanınmasındaki katkılarını da şükranla anmak gerekmektedir.

O, Türkiye'de uzun yıllar turizm, kültür ve teknik alanlarda, son derece önemli çalışmalara imza atmış, kurduğu Turing Cemiyeti sayesinde Türkiye'nin ilk turistik rehberlerini yetiştirmeye çalışmış, ilk karayolu haritası, ilk afişlerinin bastırılması, ilk yabancı dil kurslarının açılması, ilk tercüman rehber sınavları yapılması, ilk turizm incelemelerinin yazdırılması ve yayınlanması, turizm kongre ve konferansları düzenlenmesi, devlet mekanizmasının, mevzuatın ve metotların, turizm ihtiyaçları ile yeni baştan düşünülmesinin yolunu açmaya çalışmıştır.

Reşit Saffet Atabinen, Türk turizminin gelişmesini siyasi, kültürel ve ekonomik yönlerini de göz önüne alarak çok boyutlu düşünmüş ve ona göre çalışmıştır. Viyana, Milano, Roma, Floransa ve Bükreş gibi Avrupa'nın pek çok şehrinde Türkiye'yi tanıtıcı konferanslar vermiştir. Turing Kurumu turizm ve otomobil sporları bakımından dünyanın en önemli birlikleri olan "Uluslararası Turizm Birliği”, "Uluslararası Tanınmış Otomobil Kulüpleri

\footnotetext{
92 Türkiye Turing ve Otomobil Kurumu, 6 Nisan 1957 Genel Kurulu, Çituri Biraderler Basımevi, İstanbul 1957, s. 6.

${ }_{93}$ Türkiye Turing ve Otomobil Kurumu, s. 18.

${ }^{94}$ Geniş bilgi için Bkz. Türkiye'ye Bir Işıktı Turing 1977-1993 (3- Gelişmeleri Seyreden Kurum 1950-1965), s. 11 vd.
} 
Birliği", "Uluslararası Turistik Propaganda Birliği" ve Merkezi Turizm Meclisleri gibi kuruluşların idare meclislerine katılınmış ve Turing Kurumu bu çalışmaları ile Türkiye'nin turizm açısından menfaatini müdafaa edebilecek ve bu alanda gerçekleşecek yeniliklerden zamanı zamanına haberdar olacak bir konuma gelmiştir.

Yine 1930 yılında Reşit Saffet, Atina'da toplanan Balkan Birliği Konferansına Türk Hükümeti delegesi olarak katılmış ve "Balkan Turizm İttihadı" başkanlığına seçilmiştir. İstanbul ise bu birliğin merkezi seçilmiştir. Reşit Saffet ve Turing kurumunun, yabancıları Türkiye'ye gelmeye teşvik için acenteler, konsolosluklar, turing ve otomobil kulüpleri, seyahat acenteleri, fahri temsilciler ve şubeler vasıtası ile dağıtılan ve 450.000'i aşan Fransızca, İngilizce, Almanca, İtalyanca, Rumca, ve Arapça prospektüsler, afişler Türkiye hakkında konferans vermek, mecmua, risale, takvim yayınlamak, makale yazmak veya prospektüs yapmak isteyenlere memleketin güzelliklerini, abidelerini, eski eserlerini gösteren fotoğraflar göndermişlerdir. Reşit Saffet Atabinen'in turizmle ilgili fikirlerine ve yaptı̆̆ 1 çalışmalara bakarak onun Türk turizminin kurucusu, yaşatıcısı ve esaslı şekilde geliştiricisi olduğunu söylemek sanırız abartılı olmayacaktır.

\section{KAYNAKLAR}

\section{Arşiv Belgeleri, Rapor ve Nizamnameler}

Başbakanlık Cumhuriyet Arşivi,(BCA), 30.10.0.0/ 80.526.12.

BCA, 30.1.0.0/64.396.3.

BCA, 03.01./17.95.10.

BCA, 30.10/80.526.6.

$B C A, 30.10 / 229.543 .14$.

BCA, 490.01/600.77.1.

Türk Seyyahin Cemiyeti Nizamname-i Esasisi, (TTK Kütüphanesi Kayıt No. 7510, Yer No. A/5506, 1339).

Türkiye Turing ve Otomobil Klöbü'nün Istanbul Vilâyetinin 23 Mart 1931 Tarihli ve 299 Numaral İlmühaber ile Musaddak, Tadil Olunmuş Nizamnamesi, İstanbul [1931].

Türkiye Turing Klöbü Ne Yaptı, (1925-1935), Türkiye Turing Kulübü yayını No. 72, İstanbul [1936?].

Türkiye Turing Klöbü'nün 1930 Senesi Rapor ve Bilânçosu, Türkiye Turing Kulübü yayını, İstanbul 1931 . 
Turistler İ̧̧in Konuşma Kitabı, Turing Klübü yayını, İstanbul 1930.

Türkiye Turing ve Otomobil Klöbü Belleteni, No. 26-181, (Nisan 1940).

Türkiye Turing ve Otomobil Kurumu 30'uncu Yıl Dönümü, 5 Aralık 1923-1953, Çituri Biraderle Basımevi, İstanbul [y-y].

Türkiye Turing ve Otomobil Kurumu, 6 Nisan 1957 Genel Kurulu, Çituri Biraderler Basımevi, İstanbul 1957.

Türkiye Turing ve Otomobil Kurumu, 1923-1973, T.T. ve O. K.'nun 50. Ytll, Turing yayını, İstanbul 1973.

Türkiye'ye Bir Işılktı Turing 1977-1993 (1-Doğum ve Emekleme, 3- Gelişmeleri Seyreden Kurum 1950-1965), Türkiye Turing ve Otomobil Kurumu Yayını, İstanbul [1995].

\section{Makale ve Kitaplar}

[ATABINEN], Kara Şemsi Reşit Saffet, Turizm'in Harsî, Siyasî̀ ve Íktisadî Faydaları, Türkiye Turing ve Otomobil Klöbü neşriyatından, No. 48, İstanbul [1934].

ÇOKER, Fahri, Türk Parlamento Tarihi, TBMM IV. Dönem 1931-1934, II. Cilt, TBMM Vakfı yay. No. 12, Ankara 1993.

ÇORUH, Selâhattin, "R. Saffet Atabinen", Türkiye Turing ve Otomobil Kurumu Belleteni, 276-279, (Ocak-Nisan 1965).

DİKMEN, Aylin, “Turizm”, Dünden Bugüne Istanbul Ansiklopedisi, (Nuri Akbayır vd.), C. 7, Kültür Bakanlığı ve Tarih Vakfı ortak yayını, İstanbul 1994.

ERDEN, Fethi, "R. Saffet Atabinen", Türkiye Turing ve Otomobil Kurumu Belleteni, 276-279, (Ocak-Nisan 1965).

ETE, Muhlis, "Reşid Saffet Atabinen", Türkiye Turing ve Otomobil Kurumu Belleteni, 276-279, (Ocak-Nisan 1965).

EYICE, Semavi, "Reşid Saffet Atabinen (1884-1965)", Türkiye Turing ve Otomobil Kurumu Belleteni, 276-279, (Ocak-Nisan 1965).

GÜLERSOY, "Turizm Olgusunun Gelişimi”, Cumhuriyet Dönemi Türkiye Ansiklopedisi, C. 9, (yay. haz. Mücteba Anğ vd.), İletişim yay., İstanbul 1983.

, “Ölümünün 29. Yılında Reşid Safvet Atabinen”, Tarih ve Toplum, (Şubat 1994), C. 22, S. 122, s. 68.

, "Reşit Saffet Atabinen'i Anma Toplantımız", Türkiye Turing ve Otomobil Kurumu Belleteni, 79-358, (1990), 
Hayat Tarih Mecmuast, 1965/4, (Mart 1965)'dan naklen “Ölümü Dolayısıyla: Reşid Saffet Atabinen", Türkiye Turing ve Otomobil Kurumu Belleteni, 276-279, (Ocak-Nisan 1965).

HISAR, Abdülhak Şinasi, "Reşit Saffet Atabinen ve Tarihimize Dair Eseleri", Türk Yurdu, (Ekim 1955), S. 249, s. 278-284.

KOCATÜRK, Utkan, Doğumundan Ölümüne Kadar Kaynakçalı Atatürk Günlüğü, Atatürk Araştırma Merkezi yayını, Ankara 1999.

KOÇU, Reşat Ekrem, İstanbul Ansiklopedisinde “Atabinen"' den naklen Türkiye Turing ve Otomobil Kurumu Belleteni, 276-279, (Ocak-Nisan 1965).

KOMAN, M. Mesud, "Kaybettiğimiz İki Büyük Kıymet'e Ait Birkaç Satır”, Türkiye Turing ve Otomobil Kurumu Belleteni, 276-279, (Ocak-Nisan 1965).

ÖKTE, Ertuğrul Zekai, Gazi Mustafa Kemal Atatürk'ün Yurtiçi Gezileri (1923-1931), Tarihi Araştırmalar Vakfı yayını, İstanbul 2000.

ÖZTÜRK, Kazım, Türk Parlamento Tarihi, TBMM III. Dönem 1927-1931, III. Cilt, TBMM Vakfı yay. No. 10, Ankara 1993.

ŞAHIN, Gürsoy, “Atatürk Döneminde Batı'daki Olumsuz Türk ve Türkiye İmajını Düzeltme Çabaları ve Türk Seyyahin Cemiyeti’nin Bu Konudaki Çalışmaları", Afyon Kocatepe Üniversitesi Sosyal Bilimler Dergisi, Doğumunun 125. Yllında Atatürk Özel Sayısı, C. VIII, S. 3, (Aralık 2006).

ŞİMŞİR, Bilal, Atatürk İle Yazışmalar, 1920-1923, Kültür Bakanlığı yayınları, Ankara 1992.

US, Asım, "Reşid Saffet Atabinen”, Türkiye Turing ve Otomobil Kurumu Belleteni, 276-279, (Ocak-Nisan 1965).

YÜZGÜN, Arslan, "Türkiye Turizminin Boyutları”, Cumhuriyet Dönemi Türkiye Ansiklopedisi, C. 9, (yay. haz. Mücteba Anğ vd.), İletişim yay., İstanbul 1983.

“Reşid Saffet ATABINEN", Türk Kültürü, S. 29, Y1l III, (Mart 1965), s. 52-53.

“T.T.O.K. ve Çelik Gülersoy”, Çelik Gülersoy Anısına, Türkiye Turing ve Otomobil Kurumu Yayını, İstanbul 2004.

“Türkiye Turing ve Otomobil Kurumu (TTOK)", Dünden Bugüne İstanbul Ansiklopedisi, (Nuri Akbayır vd.), C. 7, Kültür Bakanlığı ve Tarih Vakfı ortak yayını, İstanbul 1994. 
Ekler

1. Ek Türk Seyyahin Cemiyeti'nin İlk Nizamnamesi

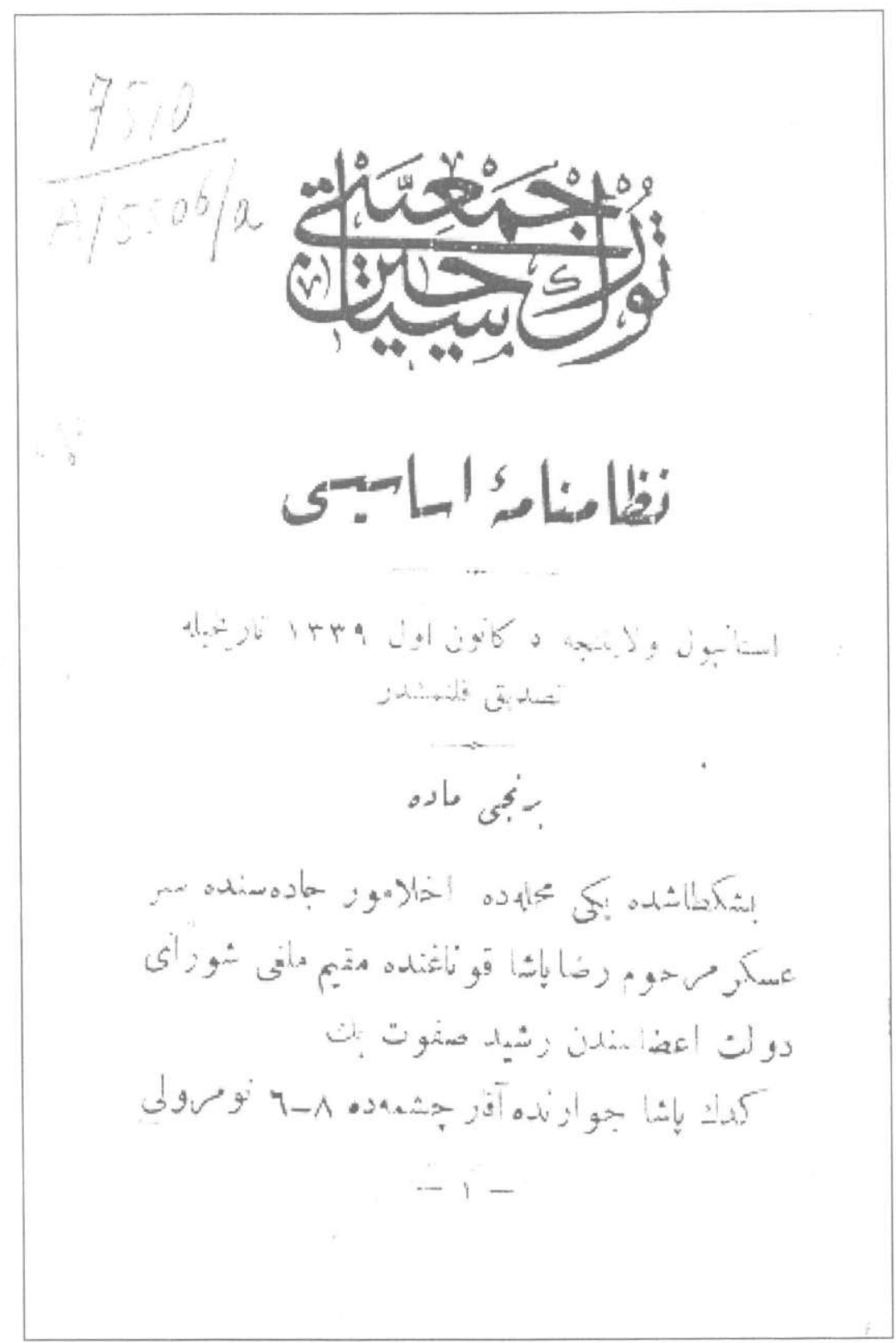

Türk Seyyahin Cemiyeti Nizamname-i Esasisi, s. 1. 
2. Ek Türkiye Turing ve Otomobil Klöbü Belleteni

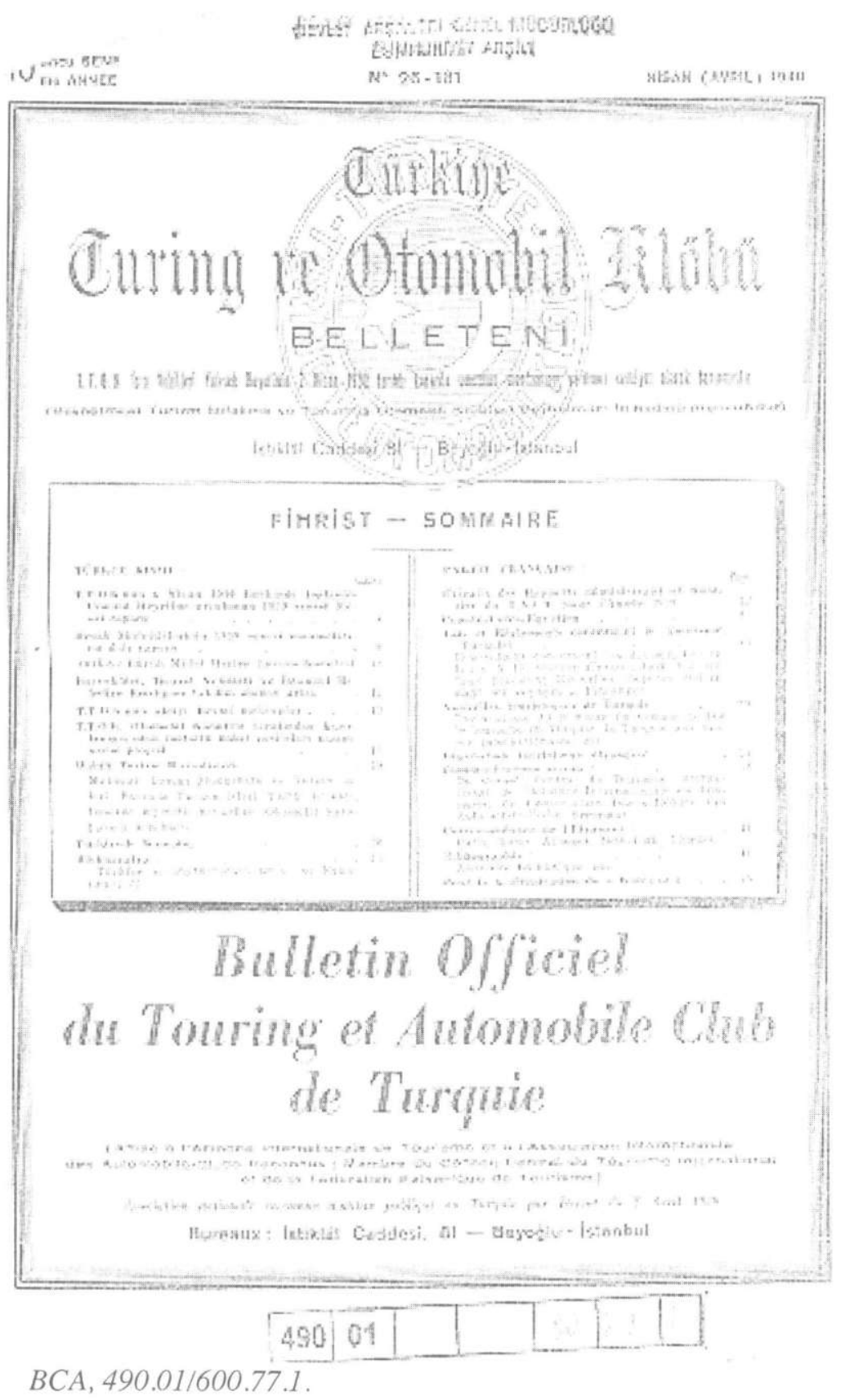

